\title{
miR-I4I-3p is a key negative regulator of the EGFR pathway in osteosarcoma
}

This article was published in the following Dove Press journal: OncoTargets and Therapy

\author{
Jiashi Wang \\ Guangbin Wang \\ Bin Li \\ Chuang Qiu \\ Ming $\mathrm{He}$
}

Department of Orthopedic Surgery, Shengjing Hospital of China Medical University, Shenyang, Liaoning, People's Republic of China
Correspondence: Ming He Department of Orthopedic Surgery, Shengjing Hospital of China Medical University, 36 Sanhao Street, Heping District, Shenyang I I0004, People's Republic of China $\mathrm{Tel}+862496615$

Fax +86 24966 I53 3III

Email topheming56@163.com
Background: Many studies have used miRNA to modulate osteosarcoma development by regulating protein expression, and these studies showed that the expression of EGFR is increased in osteosarcoma.

Methods: Western blot, real-time PCR and immunohistochemical were used to detect the expression of EGFR and miR-141 in osteosarcoma tissues and cells. The correlation between miR-141 and the grading of osteosarcoma and the correlation with the survival time of the patients were analyzed. After predicting the target effect of miR-141 on EGFR by miRDB, correlation analysis was used to analyze the correlation between miR-141 and EGFR. Luciferase reporter gene, western blot and real-time PCR were used to detect the targeting effect of miR-141 on EGFR. Then we detected the effect of miR-141 on proliferation by MTT and PI staining. The effect of miR-141 on cell apoptosis was detected by Hochest33258 and AV-PI staining, and the effect of miR-141 on cell migration was detected by Transwell. The regulatory effects of miR141 on related proteins were detected by western blot and real-time PCR. Finally, we transfected EGFR and EGFR DEL (mutation with miR-141 binding site) in osteosarcoma cells, and detected the effects of miR-141 on cell proliferation, apoptosis, migration and related proteins.

Results: The expression of miR-141-3p was negatively correlated with the expression of EGFR in osteosarcoma. The overexpression of miR-141-3p was not only closely related to the classification and size of the osteosarcoma but also had a negative effect on the growth and migration of the osteosarcoma through negative regulation of the expression of EGFR. MiR-141 can inhibit the growth and metastasis of osteosarcoma cells by targeting EGFR and affecting its downstream pathway proteins.

Conclusion: Our study provides miR-141-3p may be a new theoretical basis for the treatment of osteosarcoma.

Keywords: EGFR, osteosarcoma, prognosis, growth, migration

\section{Introduction}

Although examinations, surgery, and chemotherapy are continuously improving, the 5-year survival rate of osteosarcoma is still below $60 \% .{ }^{1}$ Osteosarcoma usually has a complex genome mutation, which was proven by many studies at the molecular level. ${ }^{2}$

Molecular target therapy is a particularly effective method for the treatment of recurrent cancer. Epidermal growth factor receptor (EGFR) is one of 4 members of the HER family of receptor tyrosine kinases. ${ }^{3}$ As EGFR can activate many signaling cascades, such as the PI3K/Akt, and Jak/STAT pathways, it plays an important role in the regulation of cell proliferation, survival, and metastasis.

MicroRNA (miRNA) is the key regulator of gene expression in many species. More than $60 \%$ of human protein coding genes are downregulated by miRNAs. ${ }^{4}$ It has been reported that the expression of miRNA in osteosarcoma is abnormal. ${ }^{5}$ Studies have 
found that miR-29 can suppress proliferation and migration via the modulation of vascular endothelial growth factor in osteosarcoma in vitro. ${ }^{6}$ In human osteosarcoma cells, apoptosis can be promoted by miR-199a-3p and miR-34a. ${ }^{7}$ miR-135b can target c-Myc in osteosarcoma and suppress the occurrence and development of cancer. ${ }^{8}$ miR-143 can suppress osteosarcoma metastasis by regulating matrix metalloproteinase (MMP)-13 expression in vitro. ${ }^{9}$ All of these data proved that miRNA plays a very important role in the development of osteosarcoma. miRNA may be a therapeutic target in the treatment of osteosarcoma.

miR-141-3p has been reported to inhibit the occurrence and development of many kinds of tumors. ${ }^{10}$ It can suppress the migration and invasion of HCC cells. ${ }^{11}$ However, there have been no reports on the expression and function of miR141-3p in osteosarcoma.

In this study, we examined the expression of miR-141-3p and EGFR in osteosarcoma and analyzed the correlation between them. It was found that miR-141-3p can inhibit the growth of osteosarcoma cells by regulating the expression of the EGFR protein.

\section{Materials and methods}

\section{Patients and tissue samples}

Thirty-two patients with primary osteosarcoma hospitalized in Shengjing Hospital between 2010 and 2015 were retrospectively analyzed. All patient information is shown in Table 1. The treatment details were as previously described. ${ }^{12}$ All patients reviewed the methods and significance of the study and provided written informed consent. The project was approved by the ethics committee for medical science research of Shengjing Hospital (R20110711). All osteosarcoma tissues were pathologically confirmed to be osteosarcoma. Before obtaining the tissue, the patient had not undergone any chemotherapy, radiotherapy, or tumor-related drug therapy.

Table I The relationship between miR-14I-3p and osteosarcoma

\begin{tabular}{|c|c|c|c|c|c|c|}
\hline \multirow[t]{2}{*}{ Parameters } & \multirow[t]{2}{*}{ Description } & \multirow[t]{2}{*}{$\begin{array}{l}\text { No of } \\
\text { patient }\end{array}$} & \multicolumn{2}{|c|}{$\begin{array}{l}\text { miR-I4I } \\
\text { expression }\end{array}$} & \multirow[t]{2}{*}{$\begin{array}{l}\text { Chi- } \\
\text { squared }\end{array}$} & \multirow[t]{2}{*}{$P$-value } \\
\hline & & & Low & High & & \\
\hline \multirow[t]{2}{*}{ Gender } & Male & 16 & 10 & 6 & 0.581 & 0.446 \\
\hline & Female & 16 & 12 & 4 & & \\
\hline \multirow[t]{2}{*}{ Age (years) } & $<40$ & 22 & 14 & 8 & 0.134 & $0.7 \mid 4$ \\
\hline & $\geq 40$ & 10 & 8 & 2 & & \\
\hline \multirow[t]{4}{*}{ TNM grade } & I & 3 & 2 & I & 8.301 & $0.040 *$ \\
\hline & II & 20 & 17 & 3 & & \\
\hline & III & 8 & 3 & 5 & & \\
\hline & IV & I & 0 & I & & \\
\hline
\end{tabular}

Note: $* p<0.05$.

\section{Western blot analyses}

To determine the expression of protein in tissues and cells, Western blot was used; whole cell extracts (lysate) were prepared from $1 \times 10^{6}$ cells or tissues in lysis buffer. Approximately $60 \mu \mathrm{g}$ of the protein was resolved on $10 \%$ sodium dodecyl sulfate-polyacrylamide gels. After electrophoresis, the proteins were electrotransferred to nitrocellulose filters, and the membrane (Amersham, Shanghai, China) was blocked with $5 \%$ nonfat dry milk in tris-buffered saline with Tween 20 for 1 hour at room temperature and incubated with primary antibody. Target proteins were probed with specific antibodies - EGFR (1:1,000), Akt $(1: 1,000)$, $\operatorname{Akt}^{\text {p-Ser473 }}(1: 1,000)$, cyclin D1 $(1: 1,000)$, bcl-2 $(1: 1,000)$, bax (1:1,000), glyceraldehyde-3-phosphate dehydrogenase (GAPDH) $(1: 3,000)$ and horseradish peroxidase-rabbit secondary antibody $(1: 5,000)$ (Santa Cruz Biotechnology Inc., Santa Cruz, CA, USA). To ensure equal loading, gels were stripped and reprobed with antibodies against GAPDH. All polyvinylidene difluoride membranes were detected by enhanced chemiluminescence (Pierce Technology, Beijing, China).

\section{Real-time polymerase chain reaction (RT-PCR)}

RT-PCR was used to detect the expression of mRNA in tissues and cells. Total RNA was extracted from tissues and MG63 cells by TRIzol (Thermo Fisher Scientific, Waltham, MA, USA) which was used to overhang cells or homogenate tissue. Add chloroform to mix and centrifuge and leave the supernatant. Add isopropanol and remove the supernatant by centrifugation. RNA was obtained after the use of ethanol to clean. The expression of miR-141-3p was detected with a Stem-Loop RT-PCR assay as previously reported. ${ }^{13,14}$ Primer sequences were synthesized as shown in Table 2.

All the reactions were carried out as described previously. ${ }^{15}$

\section{Immunohistochemical staining}

Immunohistochemical staining was used to detect the expression of EGFR in tissues. All osteosarcoma patients fulfilled the diagnostic criteria for osteosarcoma as defined in the World Health Organization classification. We used grade, tumor, metastasis (GTM) classification to evaluate osteosarcoma. G refers to the benign and malignant degree of the tumor. T refers to the range of tumor invasion. $M$ refers to regional or distant metastasis. Tissues were fixed with $4 \%$ paraformaldehyde, permeabilized for 10 minutes with PBS containing $0.1 \%$ Triton X-100 and blocked with $1 \%$ bovine serum albumin. Immunostaining was performed 
Table 2 Primers for real-time polymerase chain reaction

\begin{tabular}{|c|c|c|}
\hline Name & Forward primer $\left(5^{\prime}->3^{\prime}\right)$ & Reverse primer $\left(5^{\prime}->3^{\prime}\right)$ \\
\hline \multirow[t]{2}{*}{ miR-I4I } & ACACTCCAGCTGGGCATCTTCCAG & CTCAACTGGTGTCGTGGAGTCGGC \\
\hline & & AATTCAGTTGAGTCCAAC \\
\hline U6 & CTCGCTTCGGCAGCACA & AACGCTTCACGAATTTGCGT \\
\hline EGFR & CCTACGGGCCAGGAAATGAG & CCCAGCTGAAACTCTGACG \\
\hline Akt & GAAGGACGGGAGCAGGC & AAGGTGCGTTCGATGACAGT \\
\hline Cyclin DI & CCGAGGAGCTGCTGCAAATGGAG & GAAATCGTGCGGGGTCATTGC \\
\hline $\mathrm{Bcl}-2$ & GGTGAACTGGGGGAGGATTG & GGCAGGCATGTTGACTTCAC \\
\hline Bax & AGCTGAGCGAGTGTCTCAAG & GTCCAATGTCCAGCCCATGA \\
\hline GAPDH & СTCTGCTCCTCCTGTTCGAC & GCGCCCAATACGACCAAATC \\
\hline
\end{tabular}

Abbreviations: EGFR, epidermal growth factor receptor; GAPDH, glyceraldehyde-3-phosphate dehydrogenase.

using the appropriate primary (EGFR, 1:800) and secondary antibodies, and images were acquired using an Olympus fluorescence microscope. Immunohistochemical results were judged by HSCORE (histological score). ${ }^{16}$ Immunostaining intensity was estimated for each tissue core as follows: 1, weak; 2, moderate; or 3, strong.

\section{Survival function}

We use the Kaplan-Meier method to compute survival function. The abscissa is the survival time. The ordinate is the size of the survival function. Patients with a high expression of miR-141-3p in osteosarcoma tissues.

\section{Dual luciferase reporter assay}

Dual luciferase reporter assay was used to detect whether there is a direct binding site between miR-141-3p and EGFR. The EGFR 3' untranslated region (3'-UTR) was PCR amplified and cloned into the pMIR-REPORT ${ }^{\mathrm{TM}}$ vector (Ambion, Shanghai, China). The primers were as follows: EGFR-WT, F: 5'-CGAATGGGCCTAAGATCCCG-3', R: 5'-CGGUCGUCUCGUCAGUC-3', EGFR-DEL (Mutation of the loci of EGFR and miR-141-3p), F: 5'-CGA ATGGGCCTAAGATCCCG-3'，R: 5'-CUCGGAGAG GGAC-3'. pMIR-REPORT ${ }^{\text {TM}}-\beta$ GAL (control), miR-141-3p mimic and miR-141-3p antisense (AS) with EGFR-WT or EGFR-DEL were introduced into MG63 and HOS cells. After 36 hours, the luciferase activity was measured using the Dual Luciferase Reporter Assay System (Promega, Beijing, China) as described. ${ }^{17}$

\section{Cell count}

Cell count was used to detect the effect of miR-141-3p on cell proliferation. The cell count was also used to determine the quantity of cells after transfection with 0,50 , and $100 \mathrm{~nm}$ miR-141-3p mimic/inhibitor using a Malassez counting chamber. Cells were trypsinized from 6-well plates, and cells from each well were counted 3 times.

\section{MTT assays}

hFOB1.19 cells and human osteosarcoma cell lines HOS and MG-63 were obtained from the American Type Culture Collection (Manassas, VA, USA). MTT assay was used to detect the effect of miR-141-3p on cell proliferation. Cells were seeded in 96 -well plates; 2,000 cells in $200 \mu \mathrm{L}$ of media in each well and incubated overnight at $37^{\circ} \mathrm{C}$ in a humidified $5 \% \mathrm{CO}_{2}$ incubator. On the following day, cells were transfected with $100 \mathrm{~nm}$ miR-141-3p mimic (UAAC ACUGUCUGGUAAAGAUGG), $100 \mathrm{~nm}$ miR-141-3p inhibitor (CCAUCUUUACCAGACAGUGUUA) or control. The MTT assay was used to measure cell proliferation with a microplate reader (BIO-RAD, Beijing, China).

\section{Hoechst 33258 assay}

Hoechst 33258 assay was used to detect the effect of miR141-3p on cell apoptosis. After transfection for 24 hours, cells were washed twice with PBS, incubated with $10 \mu \mathrm{g} / \mathrm{mL}$ Hoechst 33258 for 5 minutes at room temperature, and washed with PBS 3 times. Cells were observed with a fluorescence microscope.

\section{Annexin V (AV)-propidium iodide (PI) assay}

AV-PI assay was used to detect the effect of miR-141-3p on cell apoptosis. The cells were washed twice with cold PBS, then resuspended with binding buffer at a concentration of $1 \times 10^{6}$ cells $/ \mathrm{mL}$. Then, $5 \mu \mathrm{L}$ of ANNEXIN-V-fluorescein isothiocyanate and $10 \mu \mathrm{L}$ of PI were added. The cells were incubated in the dark at room temperature for 15 minutes. Finally, $400 \mu \mathrm{L}$ binding buffer was added to each tube, and the apoptosis rate was measured by flow cytometry within 1 hour.

\section{Transwell Migration assay}

Transwell was used to detect the effect of miR-141-3p on cell metastasis. After transfection, $1 \times 10^{5}$ cells in serum-free media were seeded in transwell chambers, and then a transwell assay 
was performed. Eight hours later, cells were fixed with $4 \%$ paraformaldehyde and stained with $0.4 \%$ trypan blue.

\section{Statistical analysis}

Experiments were repeated 3 times. Analysis of variance models were used to analyze the data for each group separately.

\section{Ethics approval}

All procedures performed in studies involving human participants were in accordance with the ethical standards of the institutional and/or national research committee and with the 1964 Helsinki declaration and its later amendments or comparable ethical standards.

\section{Results}

The expression of EGFR and miR-I4I-3p in osteosarcoma tissues

To detect the expression of EGFR in osteosarcoma, tumor tissues and adjacent normal tissues were obtained from 32 patients and analyzed by Western blot (17 paired) and RT-PCR (32 paired) (Figure 1A and B). The results

A

A
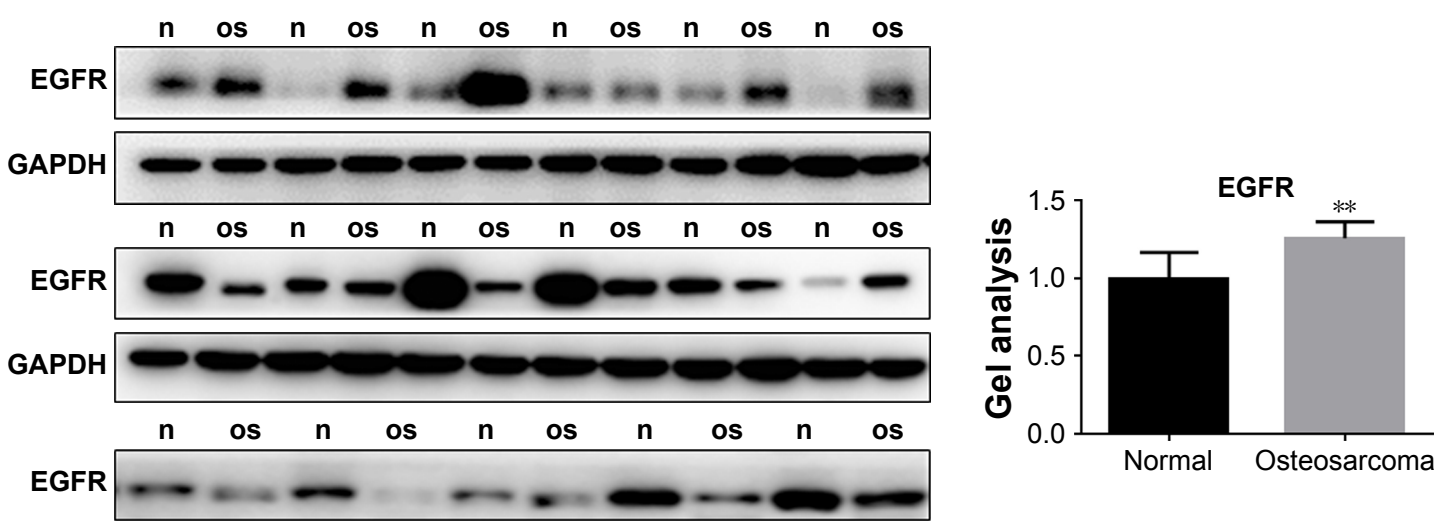

GAPDH

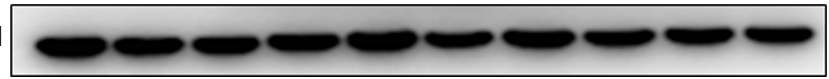

B

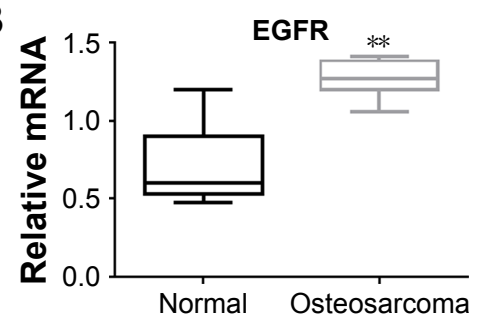

C

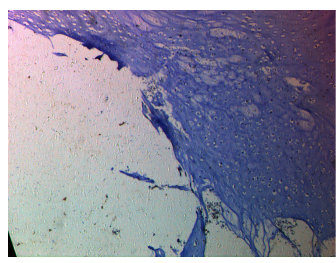

Control

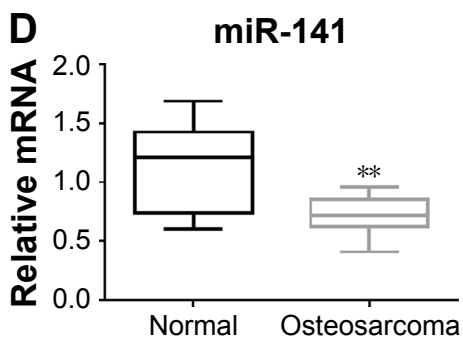

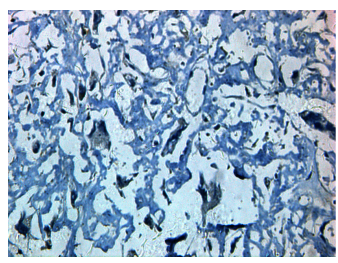

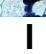

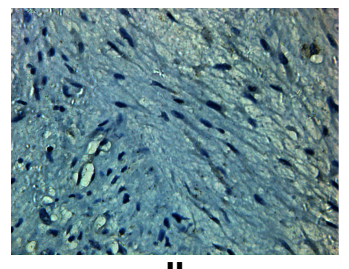

II

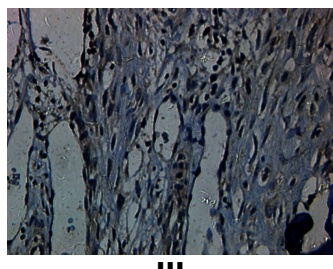

III
E

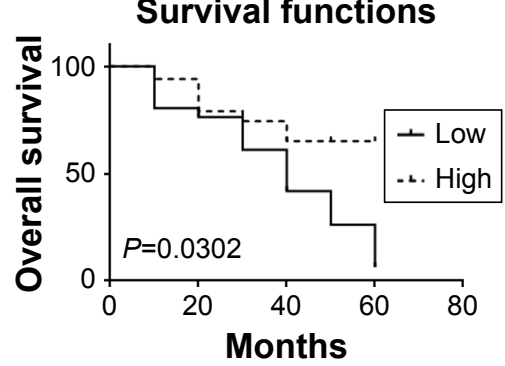

F

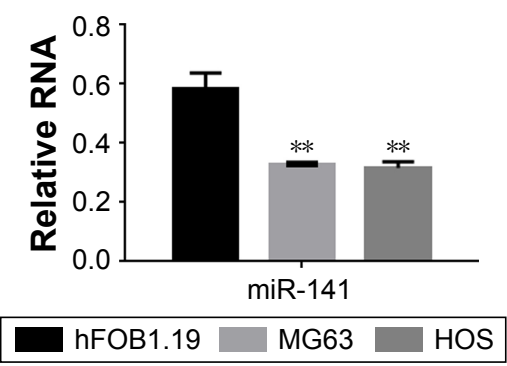


G

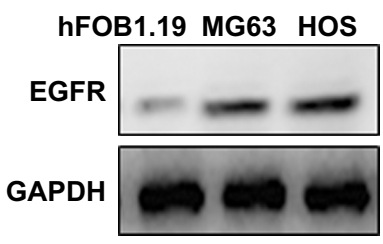

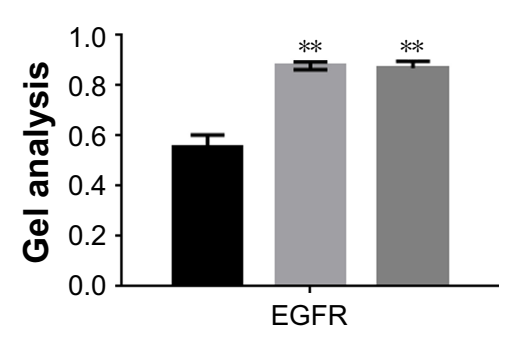

hFOB1.19
H

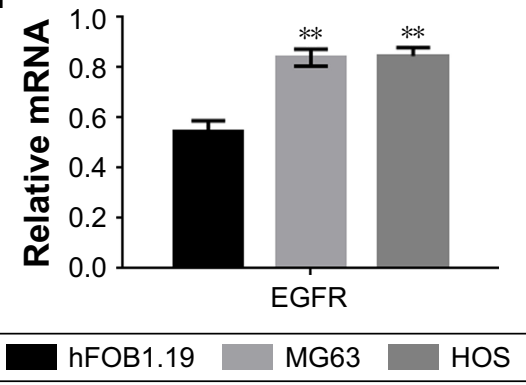

Figure I The expression of EGFR and miR-I4I-3p in osteosarcoma tissues.

Notes: (A, B) The protein and mRNA levels of EGFR expression in 32 samples of osteosarcoma tissues (os) and adjacent tissues ( $n$ ) (C). The expression of EGFR was higher in the osteosarcoma tissues than in the adjacent tissues. Data are shown as the mean \pm SEM. $* * P<0.01$ vs adjacent tissues. (C) The protein level of EGFR expression in osteosarcoma tissues. The expression of EGFR increased with an increase in the GTM grade. (D) The levels of miR-I4I-3p were detected by real-time PCR. There was a lower expression of miR-14I-3p in osteosarcoma tissues. Data are shown as the mean \pm SEM. $* * P<0.0 I$ vs adjacent tissues. (E) The expression of miR-I4I-3p was related to the survival of osteosarcoma. (F) The expression of miR-I4I-3p in cells. Data are shown as the mean \pm SEM. **P<0.0I vs hFOBI.I9 cells. (G, $\mathbf{H})$ The expression of miR-14I-3p in cells. $* * p<0.01$ vs hFOBI. 19 cells.

Abbreviations: EGFR, epidermal growth factor receptor; GAPDH, glyceraldehyde-3-phosphate dehydrogenase; GTM, grade, tumor, metastasis; PCR, polymerase chain reaction; SEM, standard error of the mean.

showed that the expression of EGFR in tumor tissues was higher than that in the adjacent tissues. At the same time, the expression of EGFR in osteosarcoma was detected by immunohistochemistry (Figure 1C). The results showed that EGFR was positively correlated with the GTM grade of osteosarcoma. Furthermore, the expression of miR-141-3p in osteosarcoma was detected by RT-PCR assay, which showed that the expression of miR-141-3p in osteosarcoma was low (Figure 1D). Patients with higher miR-141-3p expression had better prognosis than patients with low miR-141-3p expression (Figure 1E). We examined the correlation between miR-141-3p and osteosarcoma, and the results showed that miR-141-3p was associated with the classification of osteosarcoma (Table 1). We found that the expression of miR-141-3p in osteosarcoma cell lines was low according to RT-PCR (Figure 1F). The expression of EGFR in MG63 and HOS cells was higher than that of hFOB1.19 cells (Figure $1 \mathrm{G}$ and $\mathrm{H}$ ).

\section{miR-I4I-3p can inhibit the expression of EGFR}

The experiment showed that miR-141-3p can inhibit the expression of multiple proteins by using the miRDB tool (a site for miRNA target prediction and functional annotation of miRNA and target genes) (Figure 2A). Moreover, miR-141-3p can be targeted to the $3^{\prime}$-UTR region with EGFR (Figure 2B). We analyzed the results of the RT-PCR, and the expression of miR-141-3p was negatively correlated with the expression of EGFR in the osteosarcoma tissues (Figure 2C). The luciferase reporter assay was carried out to determine whether EGFR is a potential target gene of miR-141-3p (Figure 2D). The results showed that co-transfection of EGFR-WT with miR-141-3p produced lower luciferase activity in MG63 and HOS cells. However, no significant variation was observed in the cells co-transfected with EGFR-DEL or miR-141-3p AS. Western blot and RT-PCR were used to further validate the interaction of the miRNA-target (Figure 2E-L). The results showed that the content of EGFR decreased when miR-141-3p was overexpressed in MG63 cells and that the miR-141-3p overexpression and low expression cell lines were successfully constructed. When miR-141-3p was inhibited in MG63 cells, the expression of EGFR was significantly increased.

\section{miR-| $4 \mid-3 p$ inhibits the proliferation of osteosarcoma cells}

We examined the effects of different concentrations of miR-141 for MG63 and HOS cells. The results showed that the inhibitory effect of the transfection concentration of 100 nm on cells was obvious, and could be used for a follow-up experiment (Figure 3A and B). MTT assays showed that the overexpression of miR-141-3p can inhibit the proliferation of osteosarcoma cells (Figure 3C and D). Furthermore, the results showed that miR-141-3p can inhibit $\mathrm{Akt}^{\mathrm{p}-\mathrm{Ser} 473}$ and cyclin D1 and thus played a role in inhibiting cell proliferation (Figure 3E-H). The experimental results showed that miR-141-3p can affect the proliferation of cells by affecting the EGFR/Akt signaling pathway.

\section{miR-I4I-3p promotes the apoptosis of osteosarcoma cells}

The effect of miR-141-3p on the apoptosis of osteosarcoma cells was examined by Hoechst 33258 assay 
A
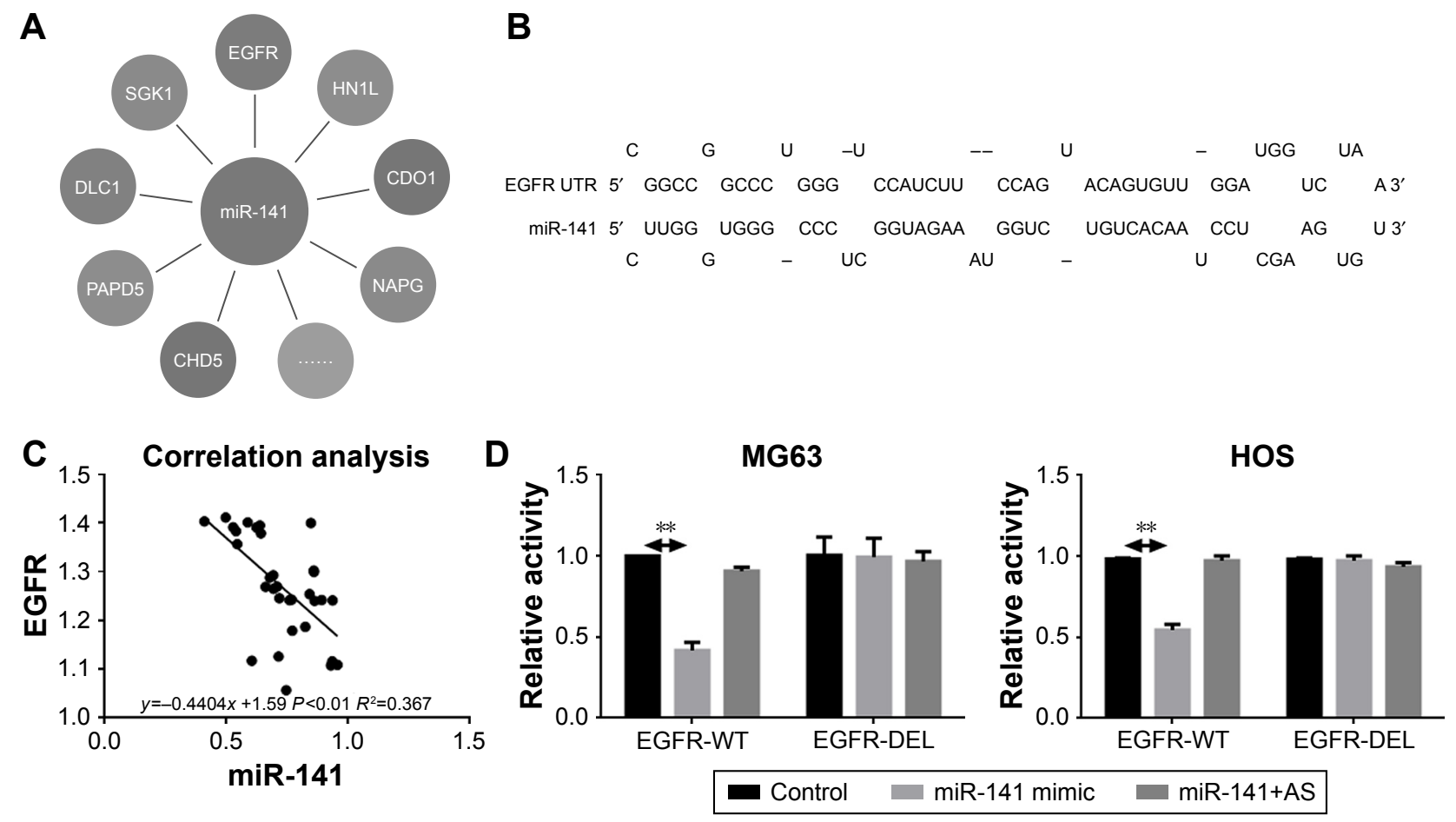

E
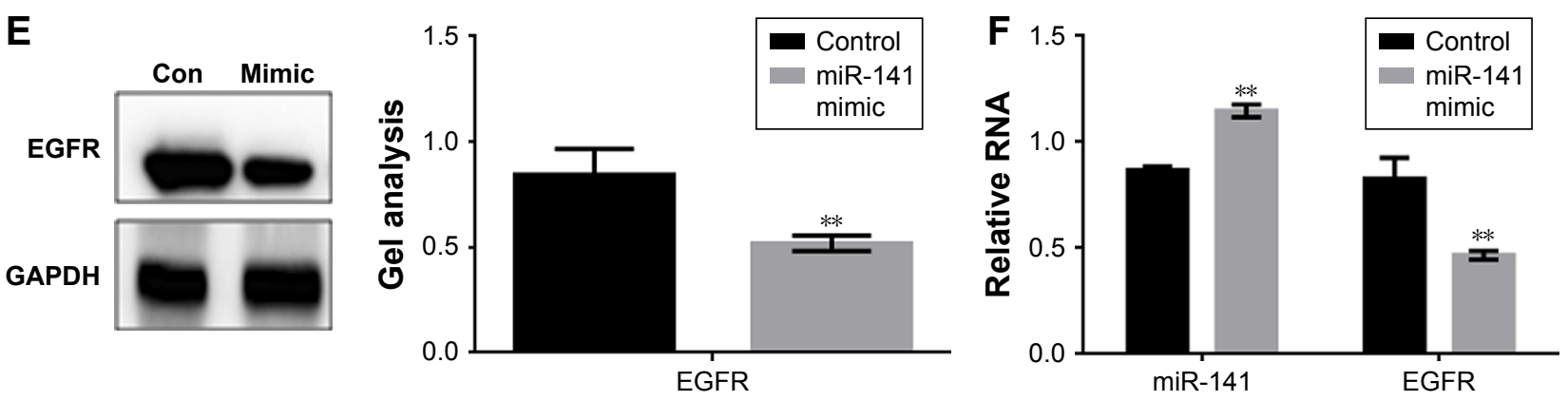

G
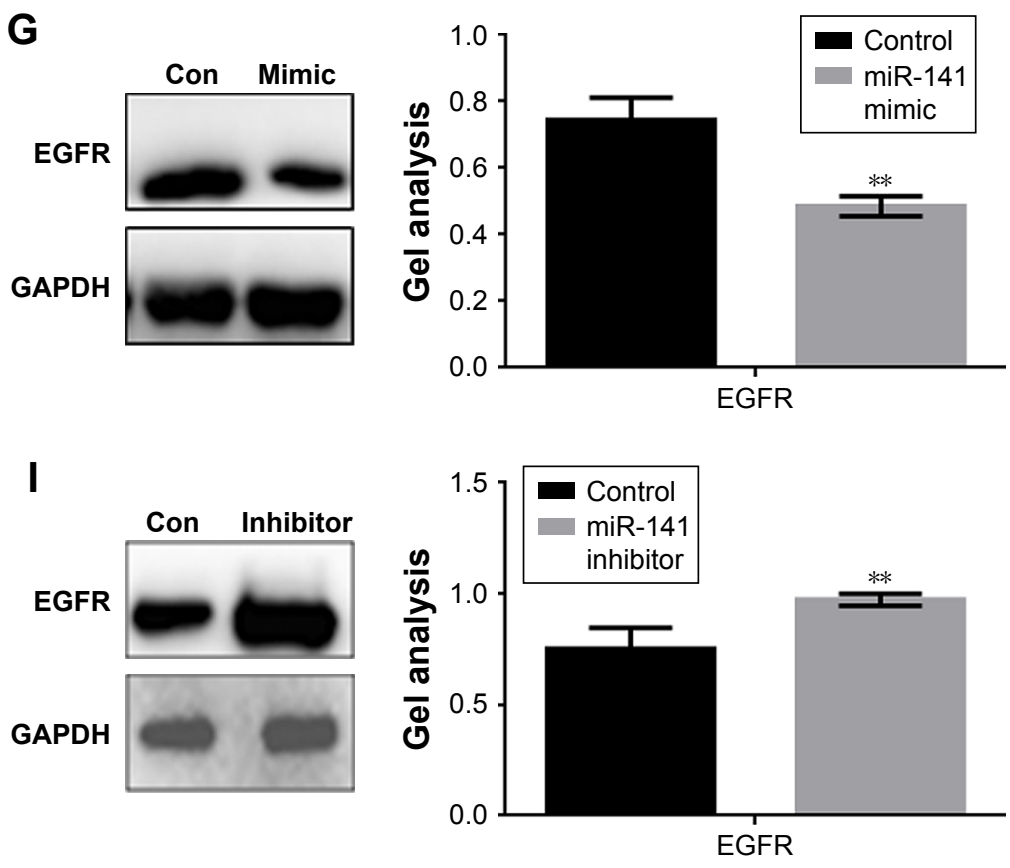

\section{B}

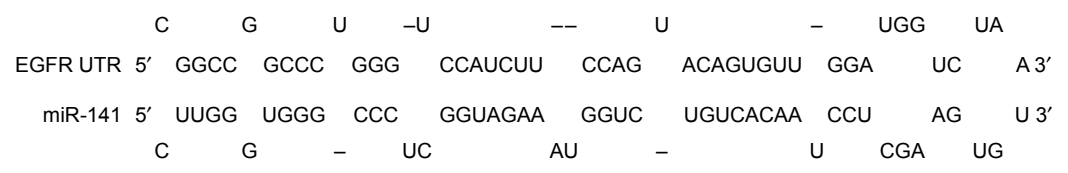



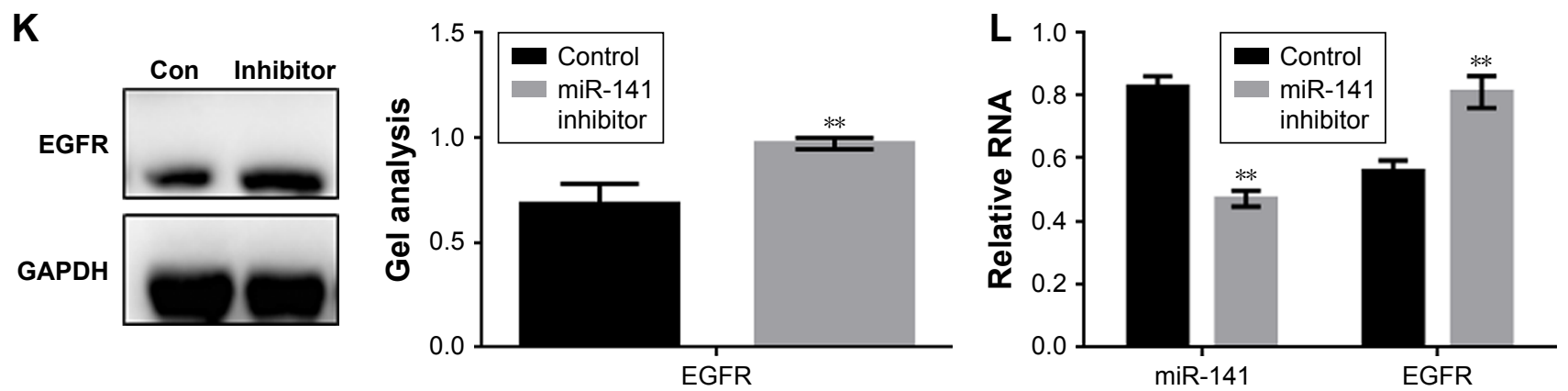

Figure 2 miR-14|-3p can inhibit the expression of EGFR.

Notes: (A) Site prediction showed that miR-I4I-3p can target several proteins. (B) miRDB predicted that miR-I4I-3p could specifically combine with EGFR. (C) The expression of miR-I4I-3p was negatively correlated with the expression of EGFR. (D) Luciferase reporter assays of the interaction between miR-I4I-3p and the EGFR $3^{\prime}$-UTR. Data are shown as the mean \pm SEM. $* * P<0$.0I vs EGFR group. (E-H) Western blot and real-time PCR showed that when the miR-I4I-3P was overexpressed/ repressed, the expression of EGFR was downregulated/upregulated in MG63 cells. Data are shown as the mean \pm SEM. $* * P<0.01$ vs control group. (I-L) Western blot and real-time PCR showed that when the miR-I4I-3p was overexpressed/repressed, the expression of EGFR was downregulated/upregulated in HOS cells. Data are shown as the mean \pm SEM. $* * P<0.01$ vs the control group.

Abbreviations: EGFR, epidermal growth factor receptor; GAPDH, glyceraldehyde-3-phosphate dehydrogenase; PCR, polymerase chain reaction; SEM, standard error of the mean; con, control.

(Figure 4A and B). The results showed that miR-141-3p could promote the apoptosis of osteosarcoma cells. In the AV-PI staining experiment, the Q4 region represents apoptotic cells, and apoptotic cells increase when miR-141-3p expression is increased (Figure 4C and D). At both the protein and RNA levels, miR-141-3p can promote the expression of bax and inhibit the expression of Bcl-2 (Figure 4E-H).

\section{miR-I4I-3p inhibits the migration of osteosarcoma cells}

Transwell assay showed that miR-141-3p could inhibit the migration of osteosarcoma cells (Figure 5A-D). miR-141-3p can inhibit the expression of MMP2, which was proven by Western blot and RT-PCR (Figure 5E-H).

\section{miR-|4|-3p inhibits the growth and migration of MG63 cells}

EGFR and EGFR-DEL plasmid were transfected into overexpressed miR-141-3p cells. The MTT assay results confirmed that the inhibitory effect of miR-141-3p on MG63 was weakened after the loss of the specific miR-141-3p combining region in EGFR (Figure 6A). Then, the effect of miR-141-3p on apoptosis and metastasis was detected by Hoechst 33258, AV-PI, and transwell assays (Figure 6B-D). The results revealed that miR-141-3p could not promote cell apoptosis or inhibit migration by suppressing EGFR-DEL. Next, the inhibitory effect of miR-141-3p on the pathway was detected by Western blot and RT-PCR. The regulatory effect of miR-141-3p on EGFR downstream proteins was
A
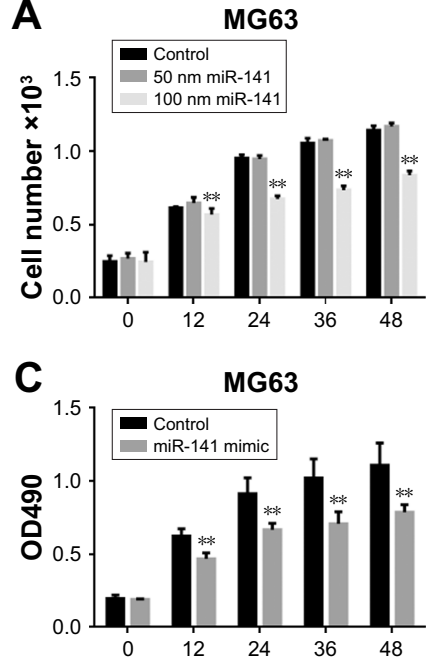
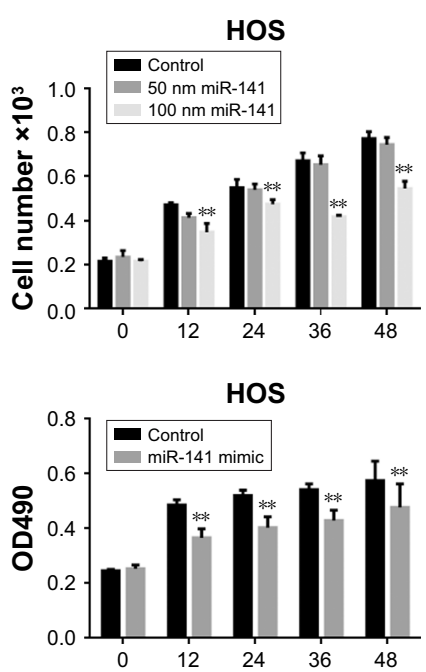

B
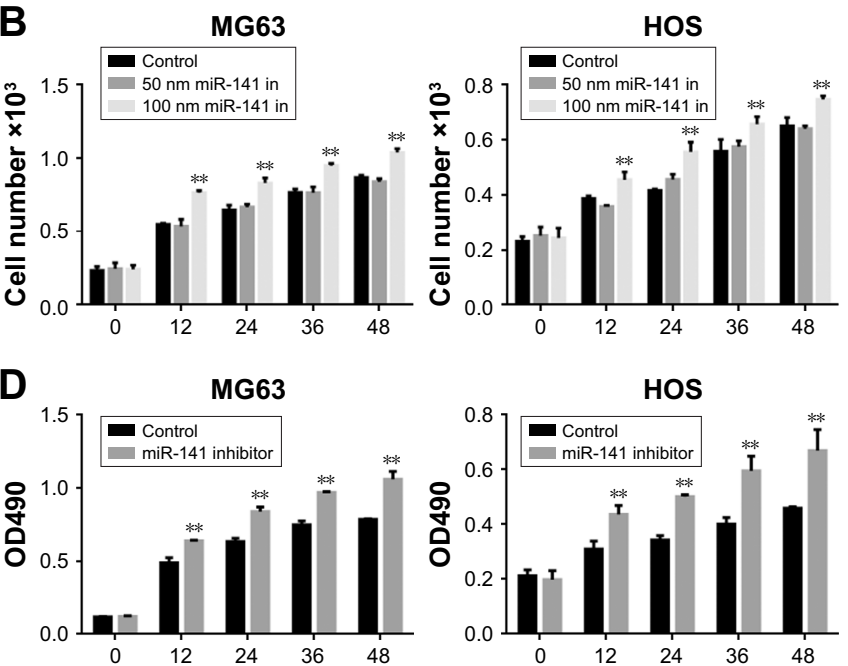

Figure 3 (Continued) 


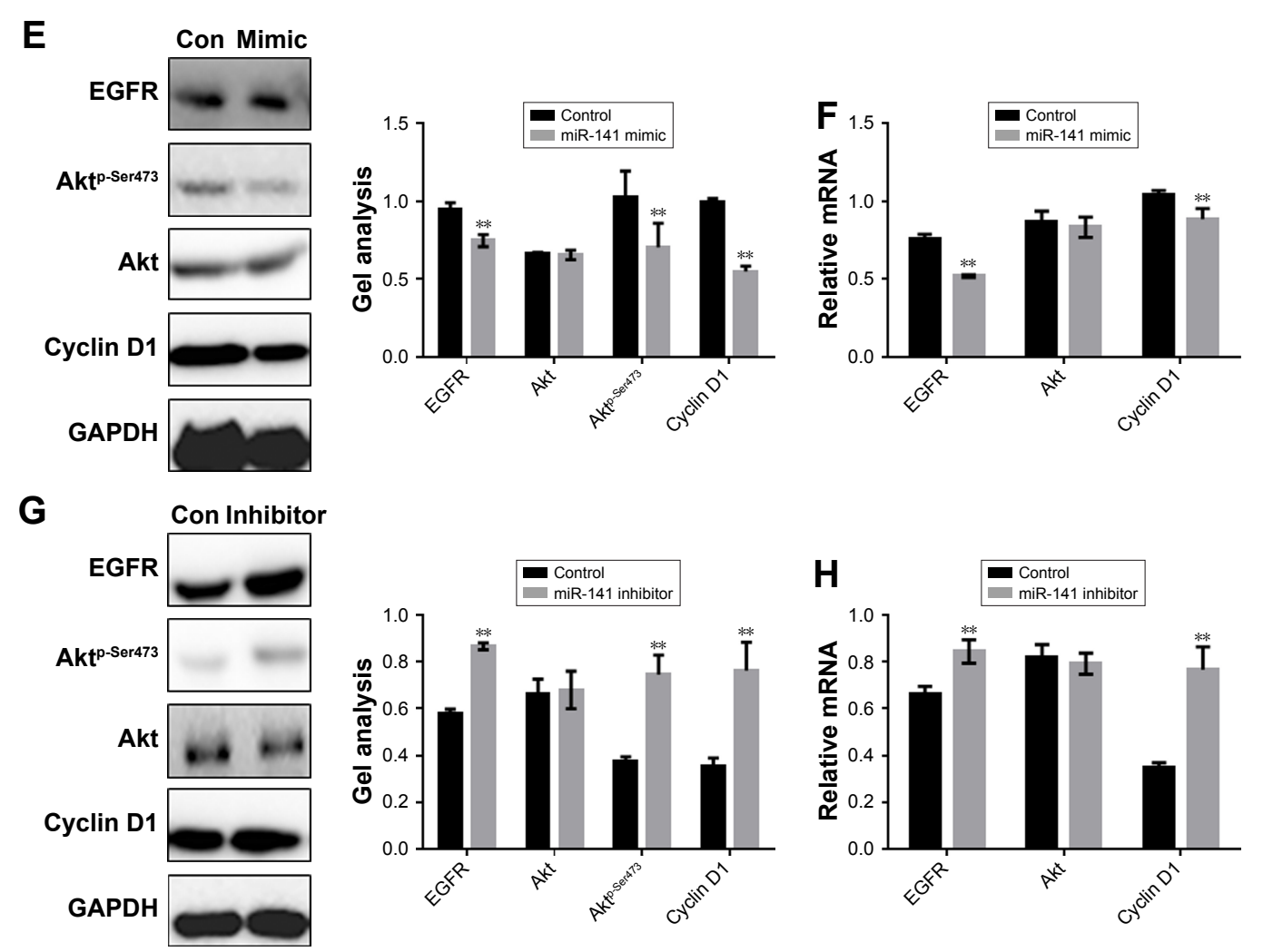

Figure 3 miR-I4I-3p inhibits the proliferation of osteosarcoma cells. (A, B) After overexpressing or inhibiting the expression of miR-I4I-3p, cell counting was performed for the same MG63 and HOS clones. Data are shown as mean \pm SEM. ${ }^{* * P}<0.01$ vs control group. (C, D) After overexpressing or inhibiting the expression of miR-I4I-3p, cell growth was detected by MTT assay. Data are shown as the mean \pm SEM. $* * P<0.01$ vs control group. (E-H) MG63 cells were overexpressed/downregulated with miRI4I-3P, and the indicated proteins and RNA levels were detected by Western blot and real-time PCR. Data are shown as the mean \pm SEM. $* * P<0.01$.

Abbreviations: EGFR, epidermal growth factor receptor; GAPDH, glyceraldehyde-3-phosphate dehydrogenase; PCR, polymerase chain reaction; SEM, standard error of the mean; con, control.

crippled when EGFR lost its specific miR-141-3p combining region (Figure $6 \mathrm{E}$ and $\mathrm{F}$ ).

\section{Discussion}

As a kind of small, endogenous and noncoding RNA, miRNA can combine with the mRNA 3'-UTR, resulting in the inhibition of mRNA translation or the degradation of mRNA. ${ }^{18}$ A large number of studies indicated that the abnormal expression of mRNA is closely related to the occurrence and development of many tumors. To date, many studies have reported that the abnormal expression of miRNA is involved in the occurrence and development of osteosarcoma. It is closely related to the prognosis of osteosarcoma. miR-141-3p is a member of the miR-200 family,
A

Con

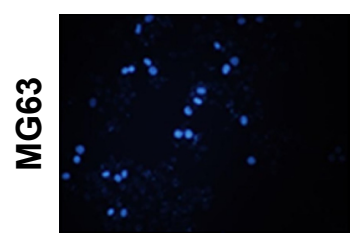

B

Con

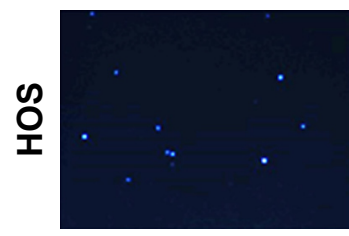

Mimic

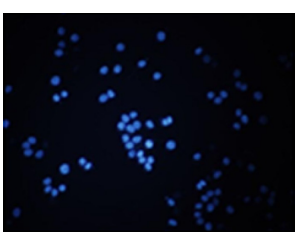

Mimic

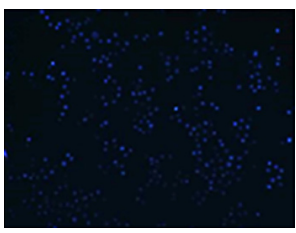

Con

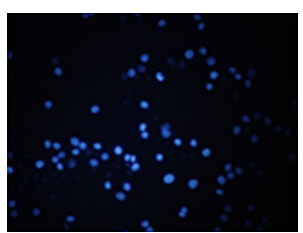

Con

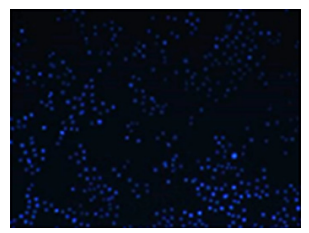

Inhibitor

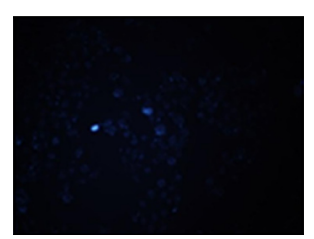

Inhibitor

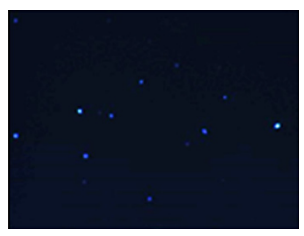



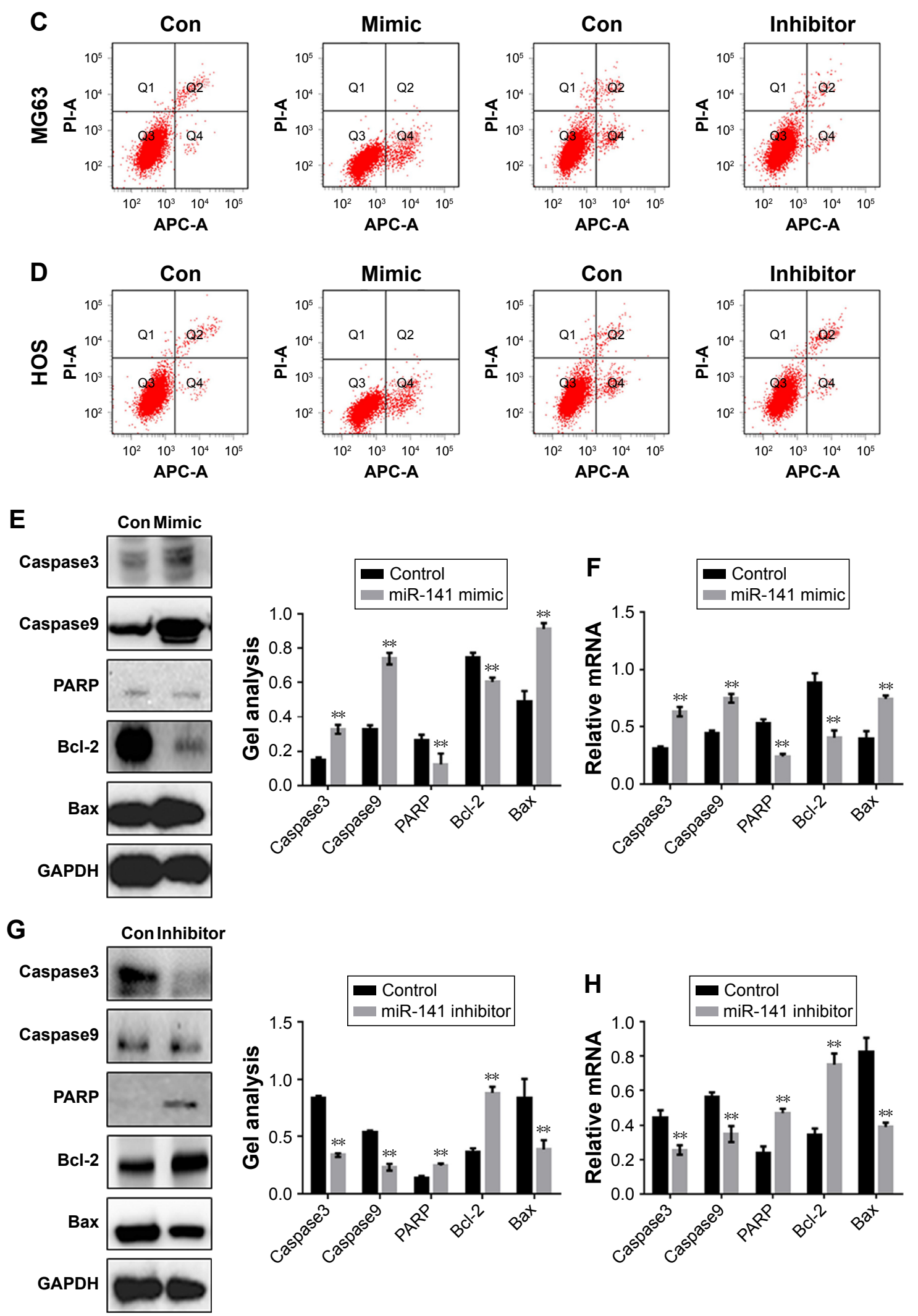

Figure 4 miR-I4I-3p promotes the apoptosis of osteosarcoma cells.

Notes: (A, B) MG63 cells and HOS cells were overexpressed or inhibited with miR-14I-3p; 24 hours later, Hoechst 33258 staining was performed. (C, D) MG63 cells and HOS cells were overexpressed or inhibited with miR-I4I-3p; 24 hours later, AV-PI assay was performed. Q4 means for apoptosis cells. (E-H) MG63 cells were overexpressed/downregulated with miR-I4I-3p, and the indicated proteins and RNA levels were detected by Western blot and real-time PCR. Data are shown as mean \pm SEM. $* * P<0.0$ I vs the control group.

Abbreviations: AV, annexin V; GAPDH, glyceraldehyde-3-phosphate dehydrogenase; PCR, polymerase chain reaction; $\mathrm{PI}$, propidium iodide; SEM, standard error of the mean; con, control. 


\section{A}

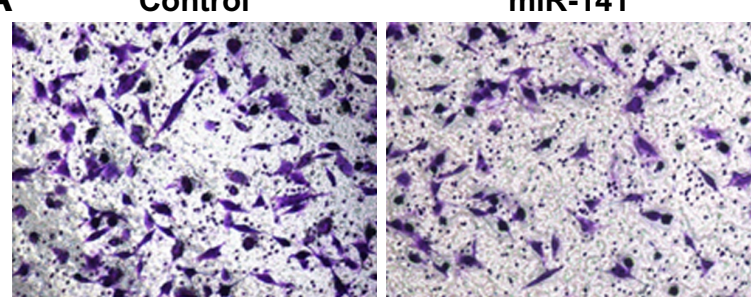

B

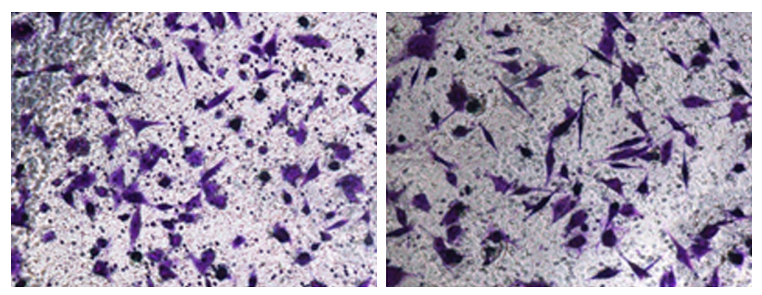

C

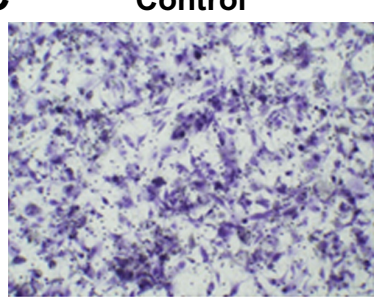

D

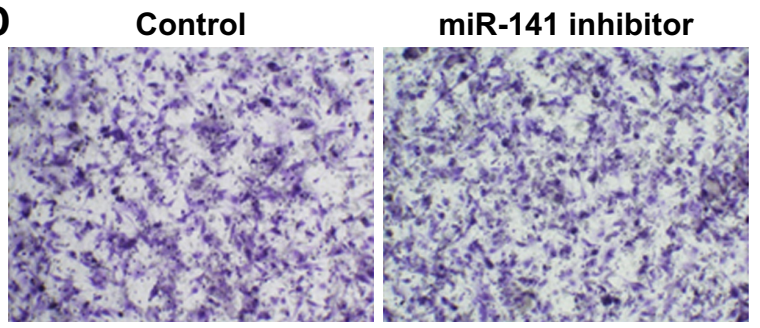

E

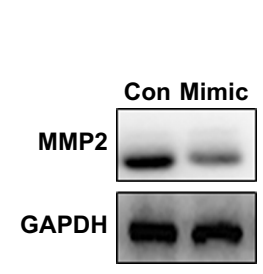

G

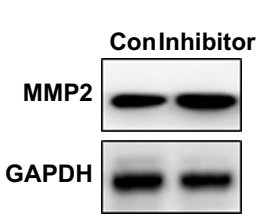

miR-141
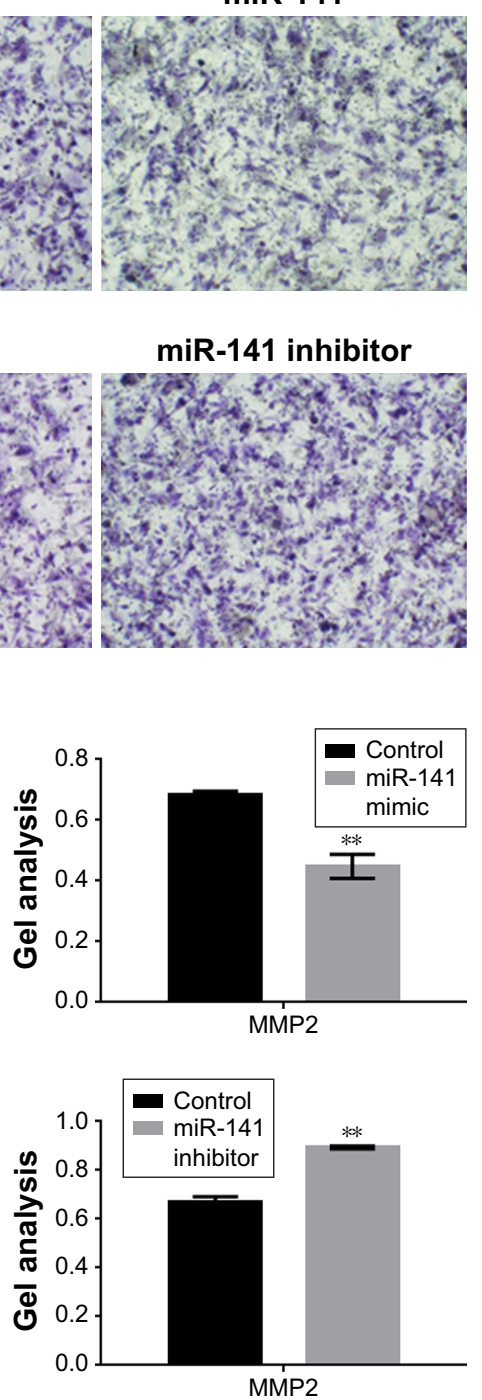

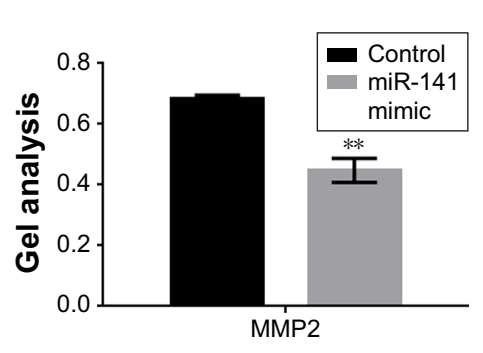

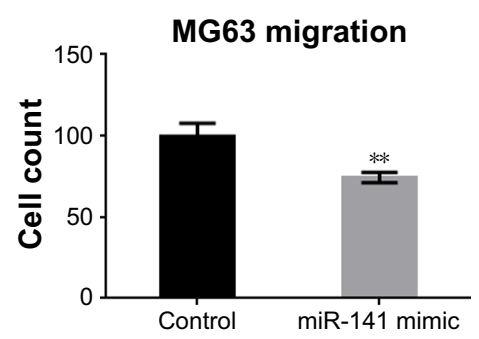
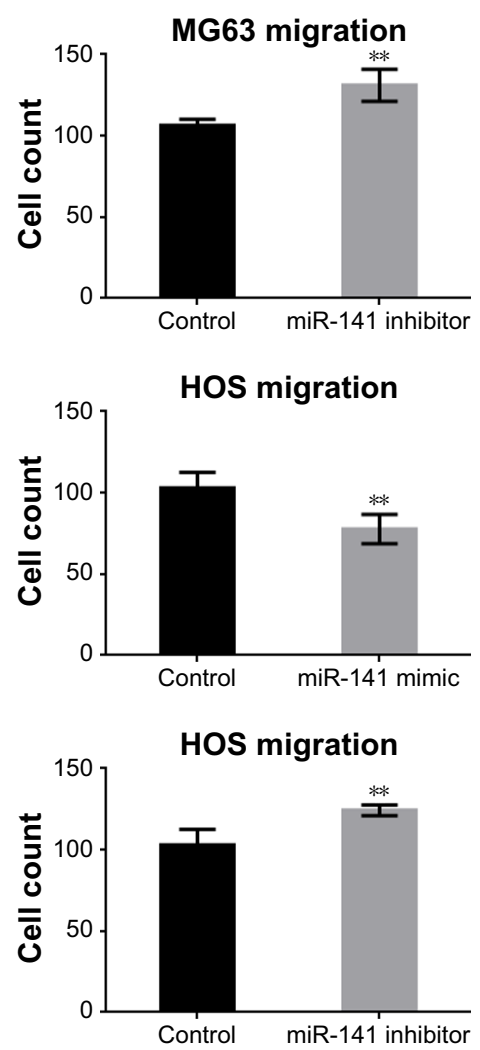

$\mathbf{F}$
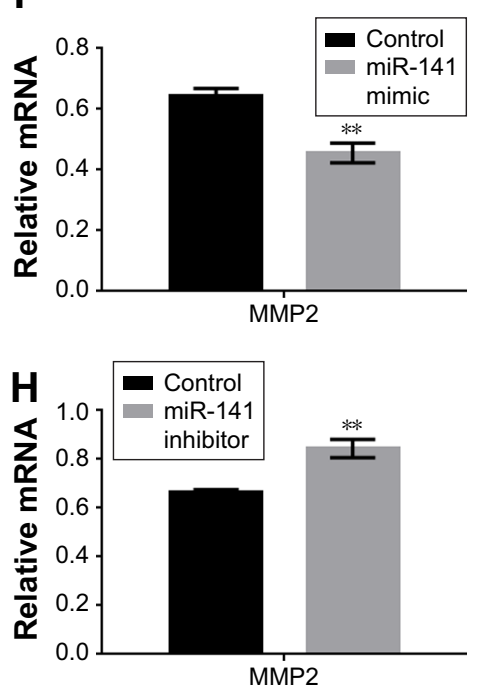

Figure 5 miR-I4I-3p inhibits the migration of osteosarcoma cells.

Notes: (A-D) MG63 cells and HOS cells were overexpressed or inhibited with miR-I4I-3p; 24 hours later, transwell assay was performed. Data are shown as mean \pm SEM. $* * P<0.01$ vs the control group. (E-H) MG63 cells were overexpressed/downregulated with miR-I4I-3p, and the indicated proteins and RNA levels were detected by Western blot and real-time PCR. Data are shown as the mean \pm SEM. $* * P<0.0$ I vs the control group.

Abbreviations: GAPDH, glyceraldehyde-3-phosphate dehydrogenase; MMP, matrix metalloproteinase; PCR, polymerase chain reaction; SEM, standard error of the mean; con, control. 
which is thought to be abnormal in a variety of tumors. It can affect the biological function of the tumor cells by regulating the expression of proteins. miR-141-3p has been found to be highly expressed in various cancers, such as ovarian cancer, ${ }^{19}$ colon cancer,${ }^{20}$ nasopharyngeal carcinoma, ${ }^{11}$ prostate cancer, ${ }^{21}$ gastric cancer, ${ }^{22}$ and breast cancer. ${ }^{23}$ Experiments showed that miR-141-3p can effectively predict the prognosis of HCC patients. The miR-141-3p/TAZ axis can inhibit the proliferation, migration, and invasion of gastric cancer cells. ${ }^{24}$ The high expression of miR-141-3p was associated with a shorter overall survival of non-small cell lung cancer patients with adenocarcinoma through angiogenesis and mesenchymal epithelial transition factor. ${ }^{25}$ miR-141-3p is upregulated in the serum of prostate cancer patients, and it may be a useful potential biomarker for the diagnosis of metastatic prostate cancer. ${ }^{26}$

The present study indicates that the EGFR inhibitor ZD6474 has a certain effect on the treatment of osteosarcoma. ${ }^{27}$ Another report showed that the anti-EGFR antibody cetuximab enhanced the cytolytic activity of natural killer cells toward osteosarcoma cells. ${ }^{28}$ However, whether the expression of EGFR in osteosarcoma plays a significant role in the occurrence and development of osteosarcoma is still controversial. ${ }^{29}$
A

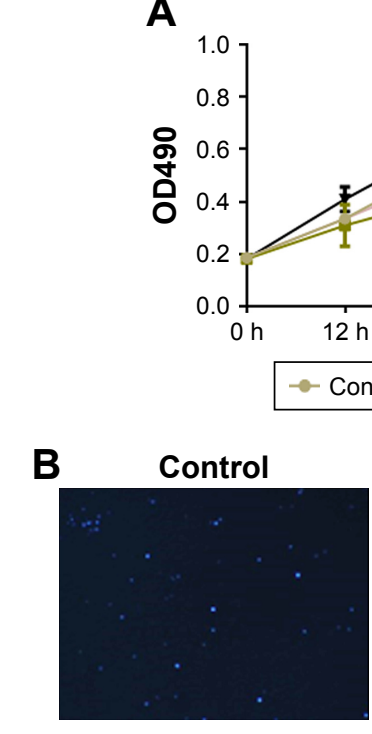

MG63
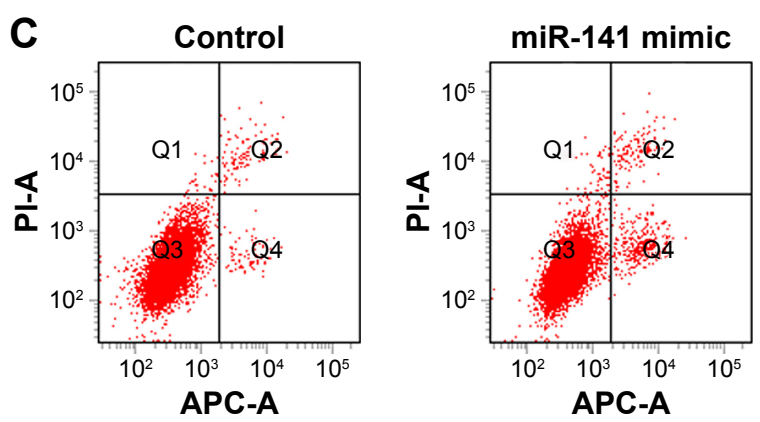

D
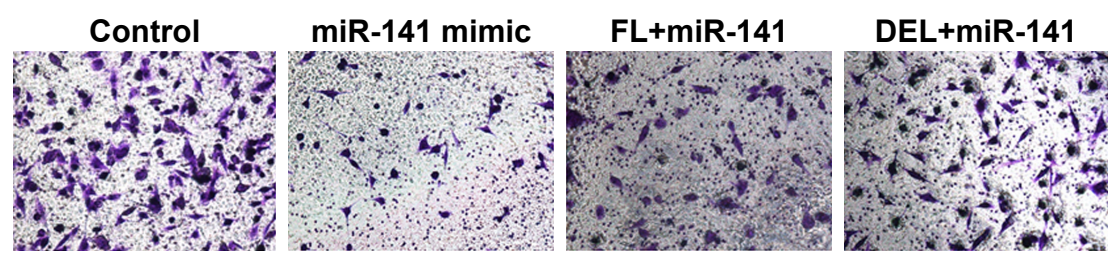

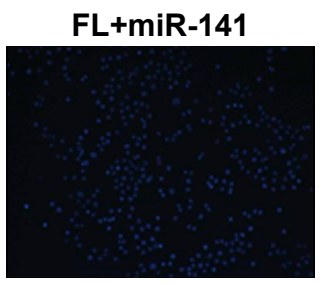

FL+miR-141
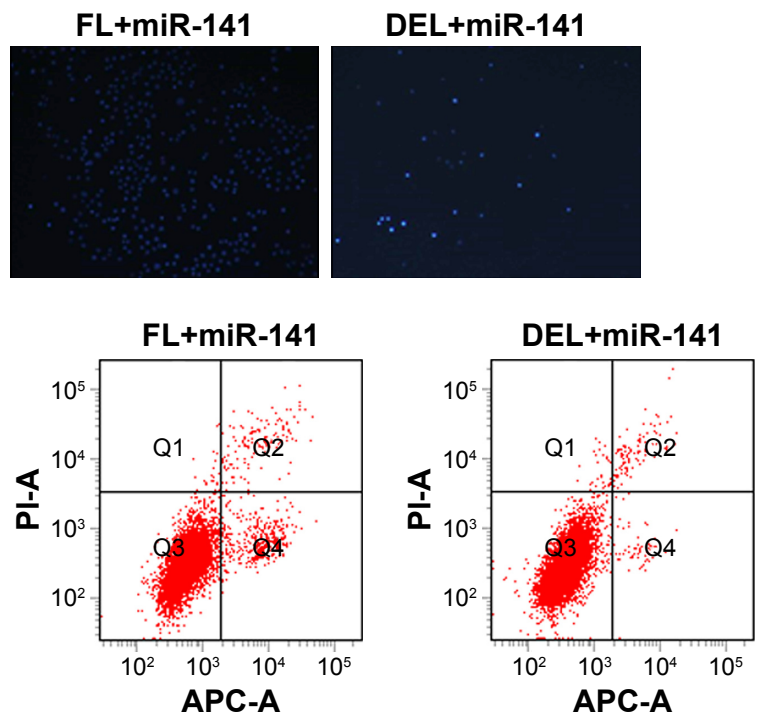

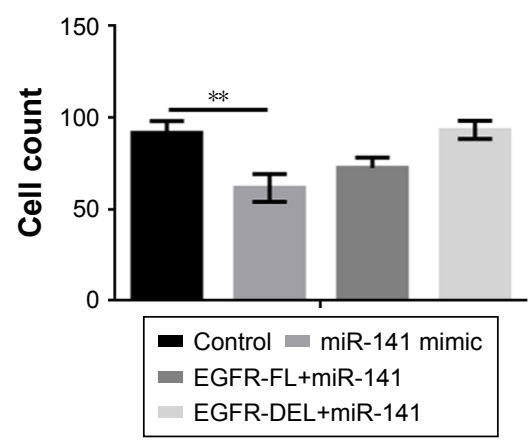

Figure 6 (Continued) 


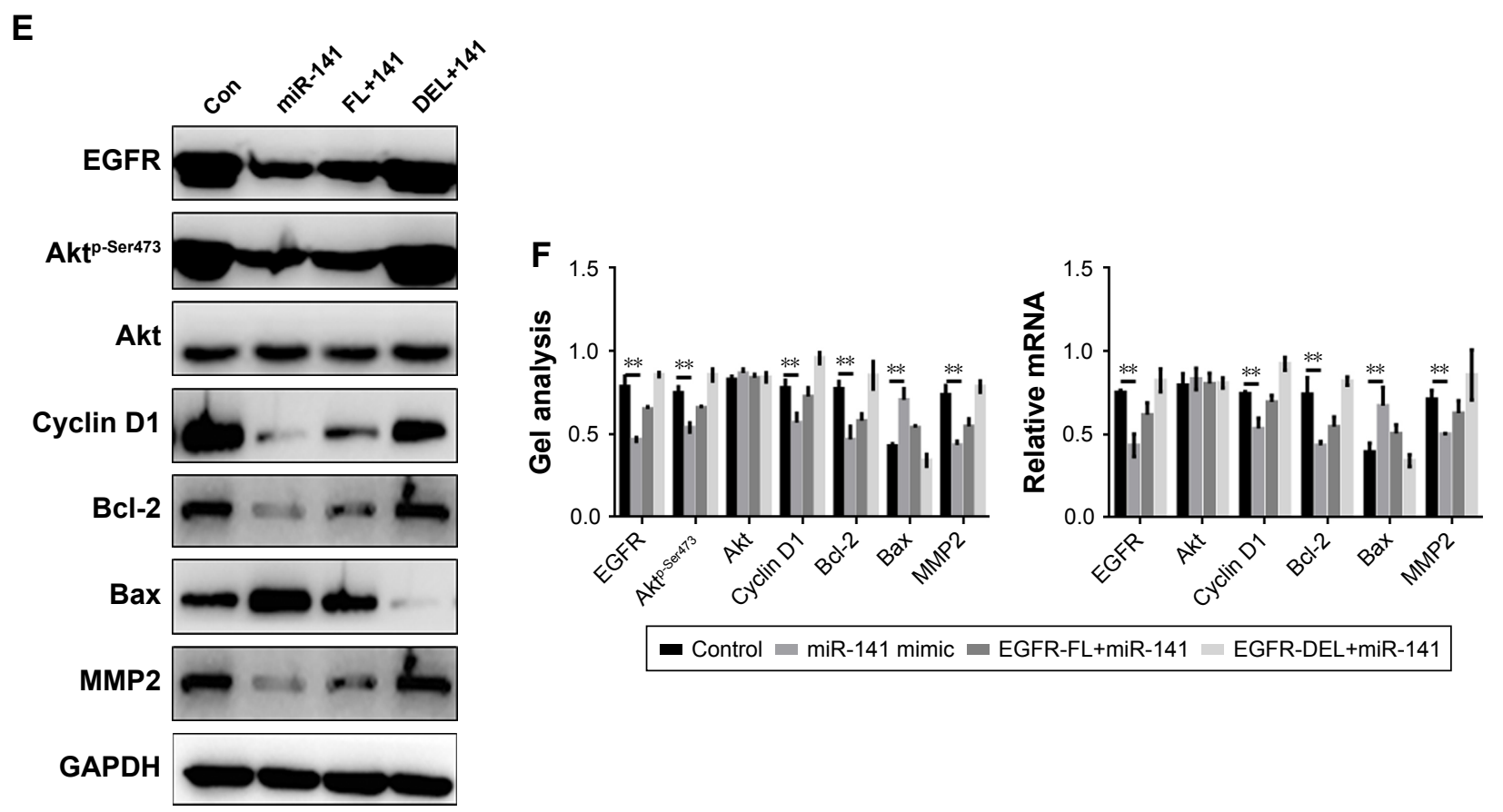

Figure 6 miR-14I-3p inhibits the growth and migration of MG63 cells.

Notes: (A) MG63 cells were overexpressed with miR-14I-3p, and then EGFR-FL or EGFR-DEL was transferred into cells. After that, the MTT assay was performed. Data are shown as the mean \pm SEM. (B) MG63 cells were overexpressed with miR-14I-3p, and then EGFR-FL or EGFR-DEL was transferred into cells. After that, Hoechst 33258 staining was performed. (C) MG63 cells were overexpressed with miR-I4I-3p, and then EGFR-FL or EGFR-DEL was transferred into cells. After that, AV-PI assay was performed. (D) MG63 cells were overexpressed with miR-I4I-3p, and then EGFR-FL or EGFR-DEL was transferred into cells. After that, the transwell assay was performed. Data are shown as the mean \pm SEM. $P<0.0$ I. (E, F) After overexpressing miR-I4I-3p, EGFR-FL or EGFR-DEL was transferred into cells. The indicated proteins and RNA levels were detected by Western blot and real-time PCR. Data are shown as the mean \pm SEM. **P $<0.01$ miR-I4I group vs the control group.

Abbreviations: EGFR, epidermal growth factor receptor; GAPDH, glyceraldehyde-3-phosphate dehydrogenase; MMP, matrix metalloproteinase; PCR, polymerase chain reaction; SEM, standard error of the mean.

In our study, we found that miR-141-3p was expressed at low levels in osteosarcoma, and there was a certain correlation between the expression of miR-141-3p and the survival rate of patients. At the same time, the expression of miR-141-3p was negatively correlated with the expression of EGFR. miR-141-3p can inhibit the expression of EGFR and the growth and migration of osteosarcoma by regulating the expression of EGFR.

In conclusion, our study showed that miR-141-3p can inhibit the occurrence and development of osteosarcoma by regulating the expression of EGFR. This suggests that miR-141-3p may play a specific role in the treatment of osteosarcoma.

\section{Acknowledgment}

All personnel who have contributed to this article are in the list of authors.

\section{Disclosure}

The authors report no conflicts of interest in this work.

\section{References}

1. Vander Griend RA. Osteosarcoma and its variants. Orthop Clin North Am. 1996;27(3):575-581.
2. Meyer S, Reinhard H, Graf N, Püschel W, Ziegler K, Schneider G. The importance of conventional radiographs in the diagnosis of osteosarcoma. Klin Padiatr. 2002;214(2):58-61.

3. Yarden Y, Sliwkowski MX. Untangling the ErbB signalling network. Nat Rev Mol Cell Biol. 2001;2(2):127-137.

4. Friedman RC, Farh KK, Burge CB, Bartel DP. Most mammalian mRNAs are conserved targets of microRNAs. Genome Res. 2009; 19(1):92-105.

5. Shen L, Wang P, Yang J, Li X. MicroRNA-217 regulates WASF3 expression and suppresses tumor growth and metastasis in osteosarcoma. PLoS One. 2014;9(10):e109138.

6. Zhang K, Zhang C, Liu L, Zhou J. A key role of microRNA-29b in suppression of osteosarcoma cell proliferation and migration via modulation of VEGF. Int J Clin Exp Pathol. 2014;7(9):5701-5708.

7. Tian Y, Zhang YZ, Chen W. MicroRNA-199a-3p and microRNA-34a regulate apoptosis in human osteosarcoma cells. Biosci Rep. 2014;34(4): pii: $\mathrm{e} 00132$.

8. Liu Z, Zhang G, Li J, Liu J, Lv P. The tumor-suppressive microRNA135b targets c-myc in osteoscarcoma. PLoS One. 2014;9(7):e102621.

9. Osaki M, Takeshita F, Sugimoto Y, et al. MicroRNA-143 regulates human osteosarcoma metastasis by regulating matrix metalloprotease-13 expression. Mol Ther. 2011;19(6):1123-1130.

10. Liu Y, Ding Y, Huang J, et al. MiR-141 suppresses the migration and invasion of HCC cells by targeting Tiam1. PLoS One. 2014;9(2):e88393.

11. Cheng H, Zhang L, Cogdell DE, et al. Circulating plasma MiR-141 is a novel biomarker for metastatic colon cancer and predicts poor prognosis. PLoS One. 2011;6(3):e17745.

12. Feng D, Yang X, Liu T, et al. Osteosarcoma of the spine: surgical treatment and outcomes. World J Surg Oncol. 2013;11(1):89.

13. Feng J, Wang K, Liu X, Chen S, Chen J. The quantification of tomato microRNAs response to viral infection by stem-loop real-time RT-PCR. Gene. 2009;437(1-2):14-21. 
14. Chen C, Ridzon DA, Broomer AJ, et al. Real-time quantification of microRNAs by stem-loop RT-PCR. Nucleic Acids Res. 2005; 33(20):e179.

15. Pfaffl MW. A new mathematical model for relative quantification in real-time RT-PCR. Nucleic Acids Res. 2001;29(9):e45.

16. Thorarinsdottir HK, Santi M, Mccarter R, et al. Protein expression of platelet-derived growth factor receptor correlates with malignant histology and PTEN with survival in childhood gliomas. Clin Cancer Res. 2008;14(11):3386-3394.

17. Cheng Z, Liu F, Wang G, Li Y, Zhang H, Li F. miR-133 is a key negative regulator of CDC42-PAK pathway in gastric cancer. Cell Signal. 2014;26(12):2667-2673.

18. Ventura A, Jacks T. MicroRNAs and cancer: short RNAs go a long way. Cell. 2009;136(4):586-591.

19. Iorio MV, Visone R, di Leva G, et al. MicroRNA signatures in human ovarian cancer. Cancer Res. 2007;67(18):8699-8707.

20. Schetter AJ, Leung SY, Sohn JJ, et al. MicroRNA expression profiles associated with prognosis and therapeutic outcome in colon adenocarcinoma. JAMA. 2008;299(4):425-436.

21. Zhang L, Deng T, Li X, et al. microRNA-141 is involved in a nasopharyngeal carcinoma-related genes network. Carcinogenesis. 2010; 31(4):559-566.

22. Du Y, Xu Y, Ding L, et al. Down-regulation of miR-141 in gastric cancer and its involvement in cell growth. J Gastroenterol. 2009; 44(6):556-561.
23. Gregory PA, Bert AG, Paterson EL, et al. The miR-200 family and miR-205 regulate epithelial to mesenchymal transition by targeting ZEB1 and SIP1. Nat Cell Biol. 2008;10(5):593-601.

24. Zuo QF, Zhang R, Li BS, et al. MicroRNA-141 inhibits tumor growth and metastasis in gastric cancer by directly targeting transcriptional co-activator with PDZ-binding motif, TAZ. Cell Death Dis. 2015;6:e1623.

25. Tejero R, Navarro A, Campayo M, et al. miR-141 and miR-200c as markers of overall survival in early stage non-small cell lung cancer adenocarcinoma. PLoS One. 2014;9(7):e101899.

26. Li Z, Ma YY, Wang J, et al. Exosomal microRNA-141 is upregulated in the serum of prostate cancer patients. Onco Targets Ther. 2015;9: 139-148.

27. Liu J, Wu J, Zhou L, et al. ZD6474, a new treatment strategy for human osteosarcoma, and its potential synergistic effect with celecoxib. Oncotarget. 2015;6(25):21341-21352.

28. Pahl JH, Ruslan SE, Buddingh EP, et al. Anti-EGFR antibody cetuximab enhances the cytolytic activity of natural killer cells toward osteosarcoma. Clin Cancer Res. 2012;18(2):432-441.

29. Lee JA, Ko Y, Kim DH, et al. Epidermal growth factor receptor: is it a feasible target for the treatment of osteosarcoma? Cancer Res Treat. 2012;44(3):202-209. 


\section{Supplementary material}

\begin{tabular}{|c|c|c|c|c|c|c|c|c|c|c|c|}
\hline Normal & Osteosarcoma & Figure IA & Figure IB & Normal & Osteosarcoma & Figure ID & Normal & Osteosarcoma & Figure IE & Months & Low \\
\hline 0.89264 & 1.287677 & & & 0.914439 & 1.287677 & & 1.22294 & $0.67995 I$ & & 10 & 1 \\
\hline 0.893341 & 1.292582 & & & 0.547052 & 1.292582 & & 1.21759 & 0.693489 & & 10 & 1 \\
\hline 0.714501 & 1.269456 & & & 0.559035 & 1.269456 & & 0.96507 & 0.709257 & & 20 & 1 \\
\hline 0.908894 & $|.24554|$ & & & 0.566293 & $|.24554|$ & & 0.967745 & 0.718807 & & 20 & 0 \\
\hline 0.952344 & 1.39122 & & & $0.87877 \mid$ & 1.39122 & & 0.620011 & 0.528638 & & 30 & 1 \\
\hline 1.27331 & 1.383256 & & & 0.9557 & 1.383256 & & 1.5525 & 0.540717 & & 30 & 0 \\
\hline 0.961454 & 1.356349 & & & 0.586258 & 1.356349 & & 0.602417 & 0.545077 & & 40 & 1 \\
\hline 0.802723 & 1.056747 & & & 0.904836 & 1.056747 & & 0.962395 & 0.747068 & & 40 & 0 \\
\hline 1.08865 & 1.241504 & & & 0.598183 & 1.241504 & & 1.319775 & 0.760767 & & 40 & 1 \\
\hline 1.085146 & 1.242699 & & & 0.604989 & 1.242699 & & 0.619749 & 0.769723 & & 50 & 1 \\
\hline 0.988435 & 1.178989 & & & 0.89396 & 1.178989 & & 0.647695 & 0.772279 & & 50 & 0 \\
\hline 0.982128 & 1.186953 & & & 0.647136 & 1.186953 & & 1.224545 & 0.825179 & & 50 & 1 \\
\hline 1.011211 & 1.253847 & & & 0.660482 & 1.253847 & & 0.625532 & 0.84274 & & 50 & 1 \\
\hline 1.421723 & 1.264996 & & & 0.949228 & 1.264996 & & 1.18977 & 0.694711 & & 60 & 1 \\
\hline 0.927466 & 1.126031 & & & 0.563421 & 1.126031 & & 1.00145 & 0.715028 & & 60 & 1 \\
\hline 0.915202 & I.II727| & & & 0.479845 & I.II727| & & 0.98112 & 0.605059 & & 60 & I \\
\hline 1.258944 & 1.403165 & & & 0.483799 & 1.403165 & & 0.676345 & 0.410262 & & 60 & 0 \\
\hline $1.27366 \mid$ & 1.390424 & & & 0.494849 & 1.390424 & & $1.5878 \mid$ & $0.62480 I$ & & 10 & \\
\hline $0.98458 \mathrm{I}$ & I.1077I5 & & & 0.499672 & 1.107715 & & 1.398955 & 0.931148 & & 10 & \\
\hline 0.879811 & 1.116076 & & & 0.503777 & 1.116076 & & 0.914245 & 0.936549 & & 10 & \\
\hline 1.260696 & 1.394804 & & & 0.505216 & 1.394804 & & 0.655435 & 0.638442 & & 20 & \\
\hline 1.261046 & 1.378479 & & & 0.994307 & 1.378479 & & 1.592625 & 0.642712 & & 20 & \\
\hline 0.910646 & 1.108909 & & & 0.520192 & 1.108909 & & I.194585 & $0.958 \mid 48$ & & 20 & \\
\hline 0.937627 & 1.268979 & & & 0.523277 & 1.268979 & & 0.659966 & 0.662207 & & 30 & \\
\hline 0.964608 & 1.399639 & & & 0.968642 & 1.399639 & & 1.429985 & 0.84887 & & 30 & \\
\hline 0.98353 & 1.302425 & & & I.196997 & 1.302425 & & 1.43694 & 0.860516 & & 30 & \\
\hline 0.965309 & 1.29924 & & & 0.979677 & 1.29924 & & 1.64559 & 0.861154 & & 30 & \\
\hline 0.954446 & 1.240309 & & & 0.676534 & 1.240309 & & 1.64559 & 0.86386 & & 30 & \\
\hline 0.675 & 1.406749 & & & 0.698849 & 1.241901 & & 1.68625 & 0.893223 & & 40 & \\
\hline 0.933072 & I.16784 & & & 0.732779 & 1.241105 & & 1.31282 & 0.937867 & & 40 & \\
\hline 0.912048 & 1.151515 & & & 0.543765 & 1.401175 & & 1.31603 & 0.589164 & & 50 & \\
\hline 0.933072 & 1.164256 & & & 0.550605 & 1.411129 & & 1.406445 & 0.498164 & & 60 & \\
\hline miR-141 & EGFR & Figure $2 B$ & Figure $2 \mathrm{E}$ & & & Control & & & 141 mimic & & \\
\hline 0.679951 & 1.287677 & & & EGFR & 0.813929 & $0.74070 \mathrm{I}$ & 0.977996 & 0.556612 & 0.483047 & 0.516434 & \\
\hline 0.693489 & 1.292582 & & & & & Control & & & 141 mimic & & \\
\hline 0.709257 & 1.269456 & & Figure $2 \mathrm{~F}$ & miR-14I & 0.851926 & 0.863442 & 0.885039 & 1.136019 & I.178995 & 1.121629 & \\
\hline 0.718807 & $|.24554|$ & & & EGFR & 0.923118 & 0.827449 & 0.723539 & 0.486442 & 0.445099 & 0.463735 & \\
\hline 0.528638 & 1.39122 & & Figure 2D & & & Control & & & 141 mimic & & \\
\hline 0.540717 & 1.383256 & & & EGFR-WT & I & I & I & 0.469963 & 0.368546 & 0.412558 & 0.933024 \\
\hline 0.545077 & 1.356349 & & & EGFR-DEL & 0.897 & 0.993 & 1.121 & 0.894 & 1.121 & 0.965 & 0.987 \\
\hline 0.747068 & 1.056747 & & Figure 2l & & & Control & & miR & 41 inhibitor & & \\
\hline 0.760767 & 1.241504 & & & EGFR & 0.818595 & 0.644859 & 0.793873 & 0.943673 & 0.975999 & 0.998253 & \\
\hline 0.769723 & 1.242699 & & & & & Control & & $\mathrm{miR}$ & 41 inhibitor & & \\
\hline 0.772279 & 1.178989 & & Figure 2J & miR-I4I & 0.817203 & 0.800918 & 0.864295 & 0.487667 & 0.484255 & 0.442202 & \\
\hline 0.825179 & 1.186953 & & & EGFR & 0.573 & 0.584 & 0.521 & 0.8096 & 0.76 & 0.861309 & \\
\hline 0.84274 & 1.253847 & & Figure $3 \mathrm{~A}$ & & & Control & & & m miR-|4I & & \\
\hline $0.6947 \mid I$ & 1.264996 & & & 0 & 0.291423 & 0.214622 & 0.239044 & 0.226611 & 0.298189 & 0.278957 & 0.20711 \\
\hline 0.715028 & $1.12603 \mid$ & & & 12 & 0.621187 & 0.612779 & 0.605093 & 0.681773 & 0.602975 & 0.65269 & 0.596409 \\
\hline 0.605059 & $|| 1727 \mid$. & & & 24 & 0.97807 & 0.939948 & 0.939666 & 0.974172 & 0.928994 & 0.936003 & 0.652845 \\
\hline 0.410262 & 1.403165 & & & 36 & 1.091807 & 1.047452 & 1.026403 & 1.067699 & I.082694 & I.0644I & 0.720475 \\
\hline 0.624801 & 1.390424 & & & 48 & 1.161624 & 1.158884 & $1.107 \mid 45$ & I. 178279 & I.186746 & I. 140675 & 0.808309 \\
\hline 0.931148 & 1.107715 & & Figure $3 \mathrm{~B}$ & & & Control & & $50 n$ & miR-14I in & & \\
\hline 0.936549 & 1.116076 & & & 0 & 0.265225 & 0.21556 & 0.220952 & 0.241902 & 0.28774 I & 0.208685 & 0.22074 \\
\hline 0.638442 & 1.394804 & & & 12 & 0.544198 & 0.555834 & 0.540096 & 0.504176 & 0.508129 & 0.588894 & 0.748543 \\
\hline 0.642712 & 1.378479 & & & 24 & 0.613246 & 0.642409 & 0.679103 & 0.659468 & 0.685794 & 0.647473 & 0.867799 \\
\hline 0.958148 & 1.108909 & & & 36 & 0.786112 & 0.768608 & 0.743417 & 0.785384 & 0.784699 & 0.717621 & 0.95349 \\
\hline 0.662207 & 1.268979 & & & 48 & 0.8547 & 0.884518 & 0.861967 & 0.857614 & 0.813871 & $0.83750 \mathrm{I}$ & 1.004312 \\
\hline 0.84887 & 1.399639 & & Figure $3 \mathrm{C}$ & & & Control & & & 141 mimic & & \\
\hline 0.860516 & 1.302425 & & & 0 & 0.190106 & 0.222629 & 0.174284 & 0.188348 & 0.190985 & 0.192743 & 0 \\
\hline 0.861154 & 1.29924 & & & 12 & 0.64367 & 0.565896 & 0.659422 & 0.507533 & 0.424544 & 0.467453 & 12 \\
\hline 0.86386 & 1.240309 & & & 24 & 0.794295 & 0.93803 & 1.008912 & 0.618122 & 0.675528 & 0.704522 & 24 \\
\hline 0.893223 & 1.241901 & & & 36 & 0.945905 & 0.944921 & I. 172336 & 0.739486 & 0.76848 & 0.612735 & 36 \\
\hline 0.937867 & 1.241105 & & & 48 & 0.992176 & 1.281613 & 1.049276 & 0.779566 & 0.841818 & 0.74065 I & 48 \\
\hline
\end{tabular}




\begin{tabular}{|c|c|c|c|c|c|c|c|c|c|c|c|}
\hline \multirow[t]{2}{*}{ High } & \multirow[t]{2}{*}{ Figure IF } & & & \multicolumn{3}{|l|}{ hFOBI.I9 } & \multicolumn{3}{|l|}{ MG63 } & \multicolumn{2}{|l|}{ HOS } \\
\hline & & miR-I4I & 0.6452 & 0.5574 & 0.5553 & 0.3233 & 0.3321 & 0.3332 & 0.2987 & 0.3123 & 0.3387 \\
\hline & \multirow[t]{2}{*}{ Figure IG } & & & hFOBI.I9 & & & MG63 & & & HOS & \\
\hline & & EGFR & 0.501193 & 0.598033 & 0.562189 & 0.877982 & 0.863068 & 0.894255 & 0.88583 & 0.83723 & 0.88324 \\
\hline & \multirow[t]{2}{*}{ Figure IH } & & & hFOBI.19 & & & MG63 & & & $\mathrm{HOS}$ & \\
\hline & & EGFR & 0.593061 & 0.511265 & 0.531772 & 0.819769 & 0.877726 & 0.820063 & 0.85052 & 0.876266 & 0.808265 \\
\hline
\end{tabular}

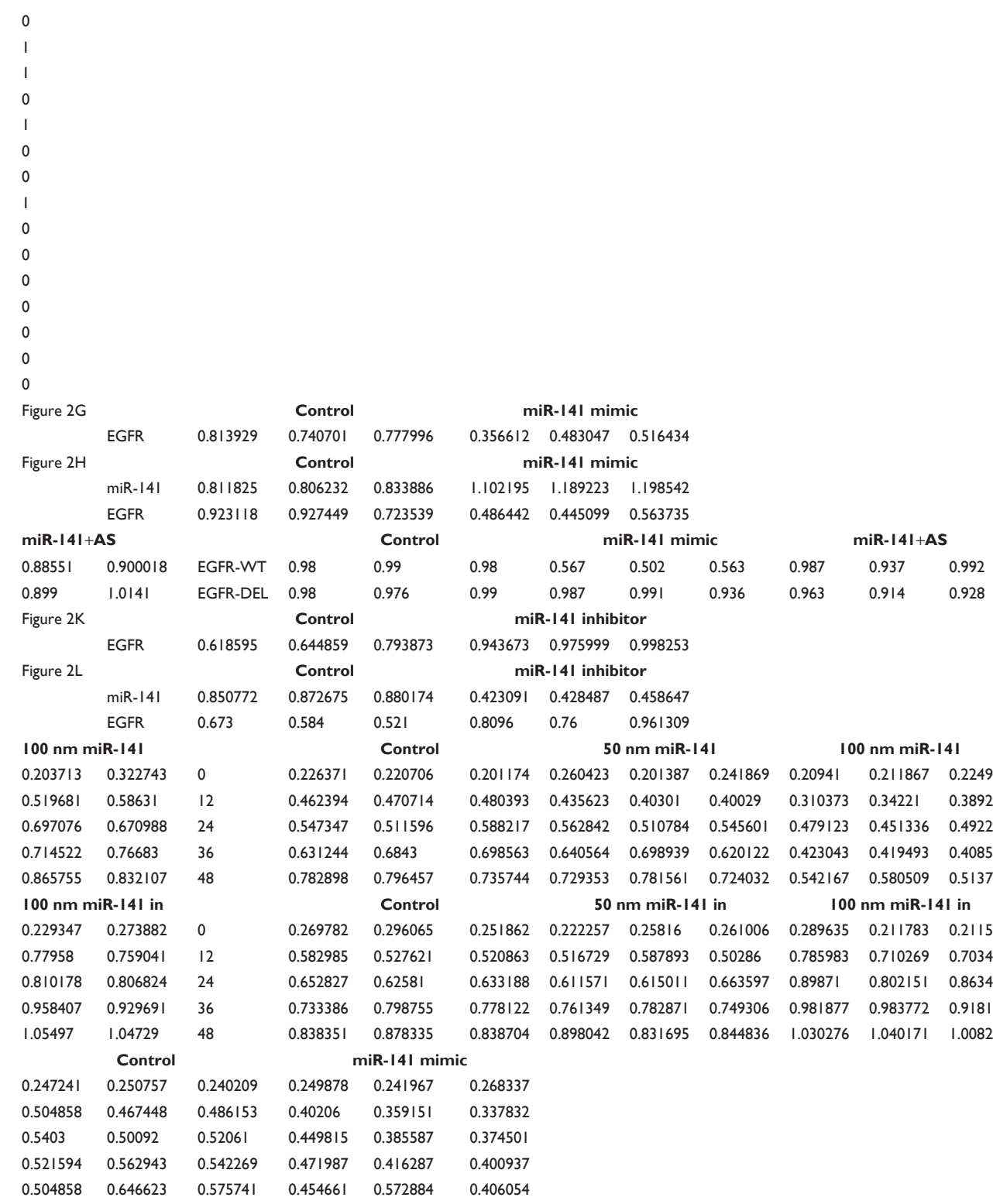


(Continued)

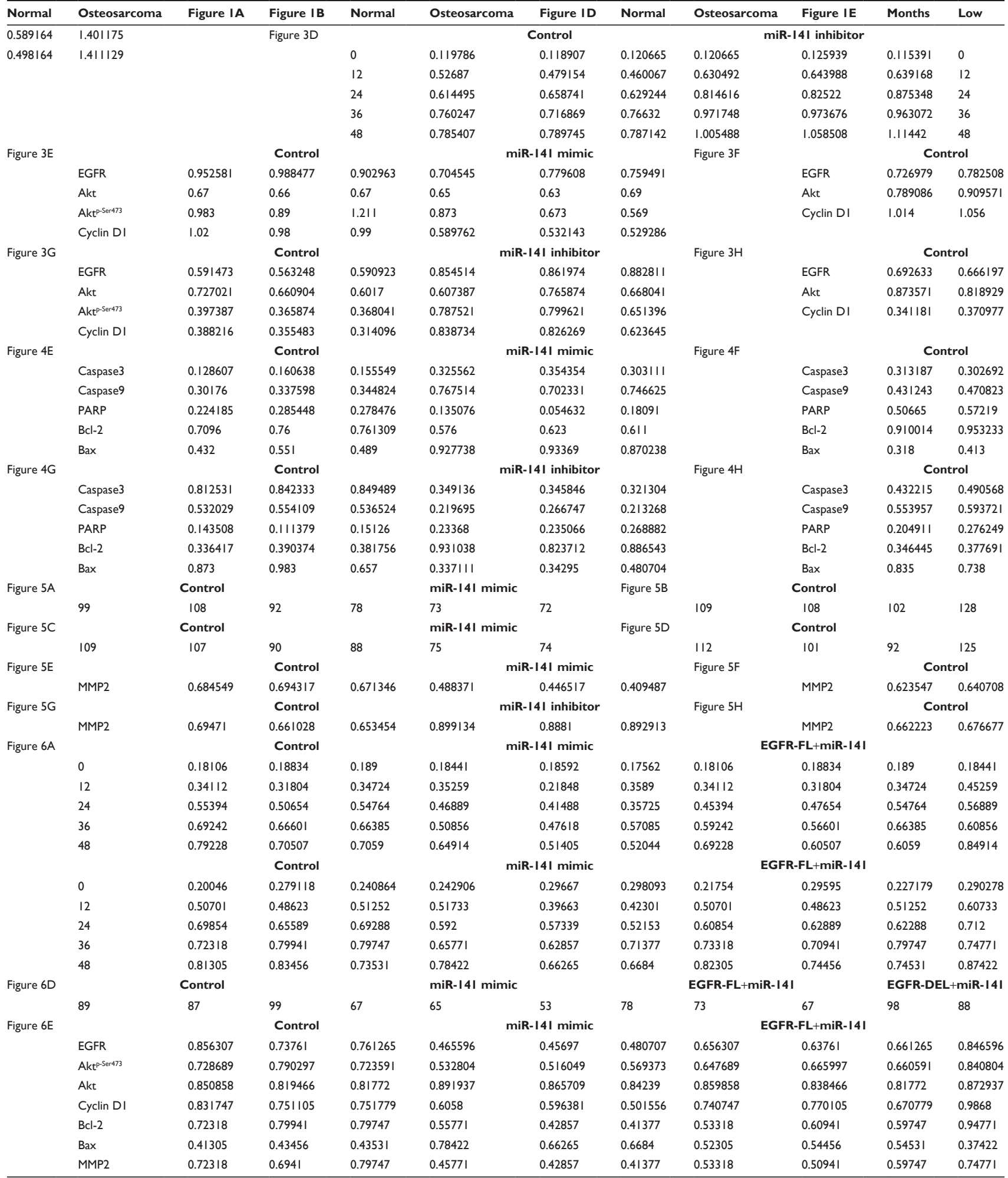

Abbreviations: EGFR, epidermal growth factor receptor; MMP, matrix metalloproteinase; in, inhibitor. 


\begin{tabular}{|c|c|c|c|c|c|c|c|c|c|c|c|c|c|c|c|}
\hline \multirow{3}{*}{$\begin{array}{l}\text { High } \\
0.211055\end{array}$} & \multicolumn{2}{|l|}{ Figure IF } & \multicolumn{3}{|l|}{ hFOBI.19 } & \multicolumn{3}{|l|}{ MG63 } & \multicolumn{4}{|l|}{ HOS } & & & \\
\hline & & & \multicolumn{3}{|c|}{ miR-14I inhibitor } & & & & & & & & & & \\
\hline & 0.285299 & 0.26733 & 0.287883 & 0.295171 & 0.224493 & & & & & & & & & & \\
\hline 0.409888 & 0.49167 & 0.403157 & 0.375692 & 0.305209 & 0.311979 & & & & & & & & & & \\
\hline 0.523221 & 0.580987 & 0.580074 & $0.40758 \mathrm{I}$ & 0.475779 & 0.467966 & & & & & & & & & & \\
\hline 0.617034 & 0.644146 & 0.68313 & 0.544678 & $0.56487 \mathrm{I}$ & 0.543867 & & & & & & & & & & \\
\hline 0.787204 & 0.709196 & 0.779054 & 0.656273 & 0.652792 & 0.612581 & & & & & & & & & & \\
\hline \multicolumn{4}{|c|}{ miR-14I mimic } & & & & & & & & & & & & \\
\hline 0.769223 & 0.514093 & 0.520124 & 0.529782 & & & & & & & & & & & & \\
\hline 0.906979 & 0.780731 & 0.906114 & 0.814469 & & & & & & & & & & & & \\
\hline \multirow[t]{2}{*}{1.061} & $0.87649 \mid$ & 0.82482 & 0.95689 & & & & & & & & & & & & \\
\hline & \multicolumn{3}{|c|}{ miR- 141 inhibitor } & & & & & & & & & & & & \\
\hline 0.629849 & 0.802612 & 0.898734 & 0.826594 & & & & & & & & & & & & \\
\hline 0.77 & 0.766429 & $0.84357 \mid$ & 0.763929 & & & & & & & & & & & & \\
\hline \multirow[t]{2}{*}{0.329199} & 0.665037 & 0.777423 & $0.857 \mid 21$ & & & & & & & & & & & & \\
\hline & \multicolumn{3}{|c|}{ miR-14I mimic } & & & & & & & & & & & & \\
\hline 0.332229 & 0.613433 & 0.68075 & 0.605028 & & & & & & & & & & & & \\
\hline 0.421942 & 0.787769 & 0.748468 & 0.712544 & & & & & & & & & & & & \\
\hline 0.507886 & 0.261598 & 0.247511 & 0.215123 & & & & & & & & & & & & \\
\hline 0.79992 & 0.477 & 0.388 & 0.356 & & & & & & & & & & & & \\
\hline \multirow[t]{2}{*}{0.452} & 0.7096 & 0.76 & 0.761309 & & & & & & & & & & & & \\
\hline & \multicolumn{3}{|c|}{ miR- 141 inhibitor } & & & & & & & & & & & & \\
\hline 0.402993 & 0.259873 & 0.227101 & 0.281723 & & & & & & & & & & & & \\
\hline 0.538475 & 0.30582 & 0.397975 & 0.341285 & & & & & & & & & & & & \\
\hline 0.242776 & 0.494545 & 0.443474 & 0.46951 & & & & & & & & & & & & \\
\hline 0.301652 & 0.678 & 0.772 & 0.801 & & & & & & & & & & & & \\
\hline 0.901 & 0.38875 & 0.415119 & 0.363929 & & & & & & & & & & & & \\
\hline$m i R-14 I i$ & nhibitor & & & & & & & & & & & & & & \\
\hline 123 & 142 & & & & & & & & & & & & & & \\
\hline$m i R-14 I i$ & nhibitor & & & & & & & & & & & & & & \\
\hline 127 & 122 & & & & & & & & & & & & & & \\
\hline & & iR-14I min & & & & & & & & & & & & & \\
\hline 0.669935 & 0.42933 & 0.445463 & 0.491881 & & & & & & & & & & & & \\
\hline & & R-14I inhib & & & & & & & & & & & & & \\
\hline 0.663598 & 0.805941 & 0.881052 & 0.845455 & & & & & & & & & & & & \\
\hline EGFR-DE & L+miR-14I & & & & & & & & & & & & & & \\
\hline 0.18592 & 0.17562 & & & & & & & & & & & & & & \\
\hline 0.41848 & 0.3589 & & & & & & & & & & & & & & \\
\hline 0.61488 & 0.65725 & & & & & & & & & & & & & & \\
\hline 0.77618 & 0.77085 & & & & & & & & & & & & & & \\
\hline 0.81405 & 0.72044 & & & & & & & & & & & & & & \\
\hline EGFR-DE & L+miR-14I & & & & & & & & & & & & & & \\
\hline 0.290155 & 0.225673 & & & & & & & & & & & & & & \\
\hline 0.59663 & 0.52301 & & & & & & & & & & & & & & \\
\hline 0.66339 & 0.70153 & & & & & & & & & & & & & & \\
\hline 0.80857 & 0.80377 & & & & & & & & & & & & & & \\
\hline 0.80265 & 0.8484 & & & & & & & & & & & & & & \\
\hline 94 & & & & & & & & & & & & & & & \\
\hline EGFR-DE & $L+m i R-14 I$ & Figure $6 \mathrm{~F}$ & & & Control & & & iR- $141 \mathrm{mir}$ & & EGF & R-FL+miR & & EGF & R-DEL+mi & $R-141$ \\
\hline 0.85697 & 0.870707 & & EGFR & 0.756307 & 0.73761 & 0.761265 & 0.465596 & 0.35697 & 0.480707 & 0.656307 & 0.53761 & 0.661265 & 0.746596 & 0.85697 & 0.870707 \\
\hline 0.897049 & 0.831373 & & Akt & 0.850858 & 0.719466 & 0.81772 & 0.891937 & 0.765709 & 0.84239 & 0.859858 & 0.738466 & 0.81772 & 0.772937 & 0.827709 & 0.82339 \\
\hline 0.827709 & 0.82339 & & Cyclin DI & 0.731747 & 0.751105 & 0.751779 & 0.6058 & 0.496381 & 0.501556 & 0.740747 & 0.670105 & 0.670779 & 0.8868 & 0.922381 & 0.963556 \\
\hline 0.922381 & 0.963556 & & $\mathrm{Bcl}-2$ & 0.62318 & 0.79941 & 0.79747 & 0.45771 & 0.42857 & 0.41377 & 0.53318 & 0.60941 & 0.49747 & 0.84771 & 0.80857 & 0.80377 \\
\hline 0.80857 & 0.80377 & & Bax & 0.41305 & 0.33456 & 0.43531 & 0.78422 & 0.56265 & 0.6684 & 0.52305 & 0.54456 & 0.44531 & 0.37422 & 0.30265 & 0.3484 \\
\hline 0.30265 & 0.3484 & & MMP2 & 0.731747 & 0.651105 & 0.751779 & 0.5058 & 0.496381 & 0.501556 & 0.540747 & 0.670105 & 0.670779 & 0.6868 & 0.922381 & 0.963556 \\
\hline 0.80857 & 0.80377 & & & & & & & & & & & & & & \\
\hline
\end{tabular}




\section{Publish your work in this journal}

OncoTargets and Therapy is an international, peer-reviewed, open access journal focusing on the pathological basis of all cancers, potential targets for therapy and treatment protocols employed to improve the management of cancer patients. The journal also focuses on the impact of management programs and new therapeutic agents and protocols on

patient perspectives such as quality of life, adherence and satisfaction. The manuscript management system is completely online and includes a very quick and fair peer-review system, which is all easy to use. Visit http://www.dovepress.com/testimonials.php to read real quotes from published authors.

Submit your manuscript here: http://www.dovepress.com/oncotargets-and-therapy-journal 